San Jose State University

SJSU ScholarWorks

Master's Projects

Master's Theses and Graduate Research

Fall 2014

\title{
Open Space Concepts for the Conversion of Former Railroad Land in the Spartan Keyes Neighborhood San José, CA
}

Shila Behzadiaria

San Jose State University

Follow this and additional works at: https://scholarworks.sjsu.edu/etd_projects

Part of the Urban Studies and Planning Commons

\section{Recommended Citation}

Behzadiaria, Shila, "Open Space Concepts for the Conversion of Former Railroad Land in the Spartan Keyes Neighborhood San José, CA" (2014). Master's Projects. 383.

DOI: https://doi.org/10.31979/etd.zmz2-xmgd

https://scholarworks.sjsu.edu/etd_projects/383

This Master's Project is brought to you for free and open access by the Master's Theses and Graduate Research at SJSU ScholarWorks. It has been accepted for inclusion in Master's Projects by an authorized administrator of SJSU ScholarWorks. For more information, please contact scholarworks@sjsu.edu. 


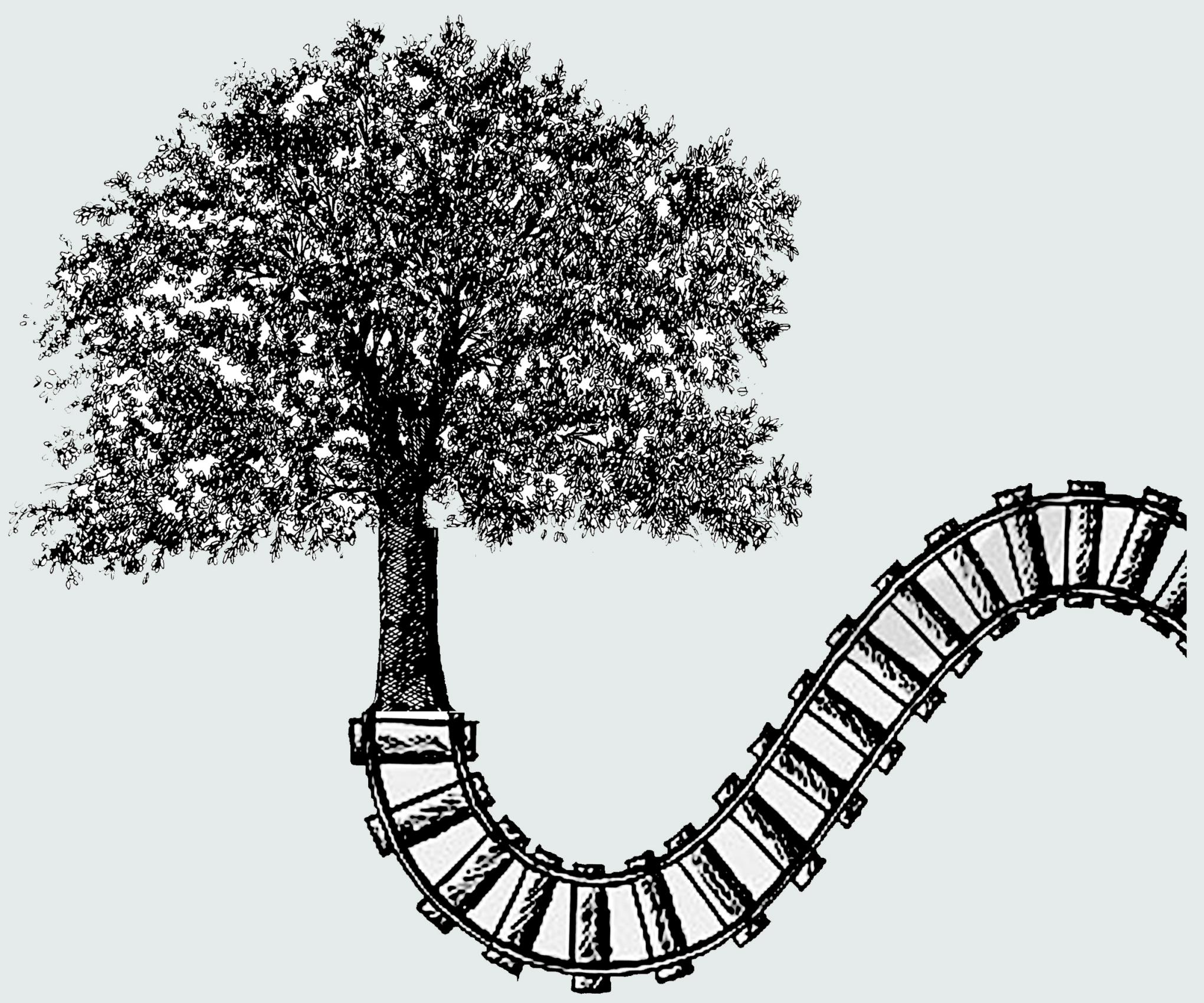

\title{
OPEN SPACE CONCEPTS FOR THE CONVERSION OF FORMER RAILROAD LAND
}

IN THE SPARTAN KEYES NEIGHBORHOOD

\author{
SAN JOSÉ, CA
}

Shila Behzadiaria

December 2014 


\title{
OPEN SPACE CONCEPTS FOR THE CONVERSION OF FORMER RAILROAD LAND IN THE SPARTAN KEYES NEIGHBORHOOD IN THE CITY OF SAN JOSÉ, CA
}

\author{
A Planning Report
}

Presented to

The Faculty of the Department of

Urban and Regional Planning

San José State University

In Partial Fulfillment

Of the Requirements for the Degree

Master of Urban Planning

By

Shila Behzadiaria

December 2014 
"Look around you. We have more than 2,000 people here today -- mayors, community activists, environmentalists, developers, bankers, entrepreneurs, officials from all levels of government -- and we're all working together toward a common vision: clean, safe, healthy, thriving communities across America."

Carol M. Browner

Administrator

U.S. Environmental Protection Agency

Opening comments at Brownfields '98

Los Angeles, California

16 November 1998 


\section{Acknowledgments}

I would like to thank the Department of Urban and Regional Planning for providing me with the opportunity to learn more about the art and science of urban planning and develop my skills in urban technology, community planning, research, data analyzing, and report writing.

My honorable advisor, Dr. Hilary Nixon, who was always available. Her assistance and advice has helped me from beginning through end of the Urban Planning Program.

Richard Kos who ispired my interest in working on this project. He is a fine teacher, a talented leader, and a great role model.

Spartan Keyes Neighborhood Action Coalition specially Rita Torres, Carol Valentine, Richard Steward, Aurelia Sanchez, and significant others for supporting me in this project. I greatly appreciate their advocacy and leadership in the Spartan Keyes Neighborhood.

All my friends, especially Robert Duncan, Mark Young, Emma Reed, and Jordan Johnson, who helped me in proof-reading. Their suggestions significantly improved the contents of this report, and encouraged me towards the completion of this project.

Lastly, I would like to thank my family, specially my mother for believing in me and allowing me to pursue my dreams. Without her support none of this would have happened. 


\section{Contents}

Acknowledgements III

List of Figures $\quad \mathrm{V}$

List of Tables $\quad \mathrm{V}$

Chapter 1: Just Say No to Brownfields! 1

Purpose of the Study 1

Research Question 1

Intended Audience $\quad 1$

Significance of Brownfield Redevelopment 2

Open Space is the Best Option $\quad 3$

Methodological Overview $\quad 4$

$\begin{array}{ll}\text { Report Structure } & 5\end{array}$

Chapter 2: Existing Conditions in the Spartan Keyes Neighborhood 6

Overview of the Neighborhood 6

$\begin{array}{lr}\text { 4th Street Line } & 9\end{array}$

Chapter 3: Pollution Concerns $\quad 12$

What is a Brownfield? 12

Revitalization Programs $\quad 12$

Revitalization Challenges $\quad 13$

Policy Recommendation $\quad 14$

Remediation Process $\quad 16$

$\begin{array}{ll}\text { Cleanup Methods } & 17\end{array}$

$\begin{array}{ll}\text { Findings } & 19\end{array}$

Chapter 4: Successful Stories $\quad 20$

Grants for Remediation of the Contaminated Land 20

Partnership for Successful Project $\quad 22$

Plan to Turn Threats into Opportunities $\quad 23$

Chapter 5: Safety Concerns $\quad 26$

Design Guidelines $\quad 27$

Crime Prevention Through Environmental Design $\quad 27$

$\begin{array}{ll}\text { Responsive Environment } & 31\end{array}$

Chapter 6: Conclusion and Recomendations

Bibliography 35 


\section{List of Figures}

Figure1 Map of Roads and Landmarks in Spartan Keyes 6

Figure 2 Zoning Map of Spartan Keyes $\quad 7$

$\begin{array}{ll}\text { Figure } 3 \text { Homeless Encampment Along Coyote Creek } & 7\end{array}$

Figure 4 Land Use Map of Spartan Keyes $\quad 8$

Figure 5 Auto Body Shop on Keyes Streeet $\quad 8$

Figure 6 Bestor Art Park $\quad 9$

Figure 7 American Can Company and 4th Street Line, View from Martha Street 9

Figure 8 Aerial View of 4th Street Line 10

Figure 9 Service Area Map of 4th Street Line in 10 to 15 Minutes Walking Distance 11

Figure 10 Aerial View of Doyle Street Greenway under Construction 20

Figure 11 New Project Entrance to the Doyle Street Greenway 21

Figure 12 Olmsted Linear Park $\quad 22$

Figure 13 Possible Future Redevelopment in Kalispell 23

Figure 14 Linear Park Development and Green Space Replacing the Railroad Track 24

Figure 15 Linear Park with Recreational Use 26

Figure 16 Active Frontage $\quad 27$

Figure 17 High Visible Gate $\quad 28$

Figure 18 Emergency Call Box $\quad 30$

Figure 19 Neighborhood Watch Sign $\quad 30$

Figure 20 Responsive Environment Diagram 31

Figure 21 Current and Recomended Access Points to 4th Street Line 32

Figure 22 Neighborhood Action Center, view from 3rd Street 32

Figure 23 Flexible Open Space

Figure 24 Light and Shade $\quad 34$

\section{List of Tables}

Table 1 Brownfield Revitalization Challenges 14

Table 2 Brownfield Revitalization Benefits 15

Table 3 Brownfield Revitalization Policy Recommendation 16

Table 4 CPTED Natural Surveillance Design Guidelines 28

Table 5 CPTED Access Design Guidelines 29

Table 6 CPTED Maintenance Design Guidelines 29

Table 7 CPTED Landscaping Design Guidelines 30 


\section{Chapter 1: Just Say No to Brownfields!}

\section{Purpose of the Study}

This project aims to analyze the feasibility of converting an abandoned brownfield in the SpartanKeyes neighborhood, which happens to be a former railroad right-of-way, into an open space such as a linear park, plaza, or community garden. In order to create a vibrant development that provides safety and economic growth, the open space can include some local commercial uses such as coffee shops or can be open to food trucks or mobile vendors. A new linear park in the Spartan Keyes neighborhood can not only meet the community's need for open space, but also can provide many social and ecological benefits for the neighborhood.

There are different reasons preventing the former railroad site from being developed as a park or open space, such as cleanup and purchasing costs, shape of the parcel, safety constraints, and soil contamination. This study will attempt to provide a better knowledge of the reasons preventing this particular parcel from being redeveloped as well as recommendations to address those constraints. This document can be used to convince the City of San José and the County of Santa Clara to provide funding for the redevelopment of this abandoned railroad parcel. The end results of this study will provide the Spartan Keyes neighborhood leaders with evidence to support their desire of redeveloping the abandoned railroad parcel into a linear park.

\section{Research Question}

Since the identified major two challenges for the redevelopment of this site are safety and contamination, this project aims to answer the following question:

- Considering brownfield remediation policies, safety design guidelines, and successes in other cities, how can the abandoned railroad parcel in Spartan Keyes neighborhood be converted into an open space or community recreational amenity?

\section{Intended Audience}

Contemporary urban planning practitioners are looking for ways to respond to the repercussions of industrialization of cities. Brownfield development has recently become popular among governments, communities, and environmental advocates. Therefore, many researchers and scientists around the world are looking for solutions to solve the problem of reusing brownfields. Brownfield redevelopment is very popular among scholars in several academic fields. ${ }^{1}$

1 Ye Chen et al., "A Strategic Classification Support System for Brownfield Redevelopment," Environmental Modeling and Software 24 (2009): 647. 
Governmental authorities and private agencies nationwide are responsible for the revitalization of vacant lands, brownfields, and abandoned railroad lines. Some also provide funding for converting brownfields into parks, trails, and community gardens. ${ }^{2}$

The primary intended audience for this research document includes the City of San Josés Planning, Building, and Code Enforcement Department, the City's Environmental Services Department, the City's Parks, Recreation and Neighborhood Services Department, residents of the Spartan Keyes neighborhood, and Spartan Keyes neighborhood community leaders. However, the audience for this research study could also simply be anyone concerned about the city's wellbeing and brownfield redevelopment. The research study is instructive for urban planners as well as environmental designers who can implement similar methodologies for similar parcels.

\section{Significance of Brownfield Redevelopment}

Due to population growth, cities have expanded into suburbs and many parcels within the center of the city have been vacated. These abandoned parcels, which are frequently contaminated by their previous uses, have resulted in a gap within the urbanized area. Owners are reluctant to sell or redevelop contaminated lands because of difficult remediation processes and high cleanup costs. ${ }^{3}$ In addition to encouraging urban sprawl, ignoring urban soil contamination, such as heavy metal concentrations, poses a potential risk to public health. Overall, abandoned brownfields have become a major problem for cities, and their remediation and redevelopment is challenging for both developers and policy makers. The challenges of brownfield redevelopment process range from purchasing the land to managing redevelopment. Brownfield redevelopment is more challenging when the brownfield is intended to become a park or an open space.

This project is worthy of study for a number of reasons. First, based on population projections and deficiency of land, the vacant parcel is an important resource for helping San José to accomplish its goals of fostering more high-density, mixed-use urban districts. ${ }^{4}$ The parcel's approximate location to the San José downtown area (the core of the business and financial district), has always been at the center of attention for land developers. Second, vacant land tends to become a space for the homeless to stay, with negative effects on the urban landscape and the sense of community for the neighborhood. Third, vacant brownfield sites can also negatively affect the value of properties in close proximity; and fourth, from an environmental justice point of view, neighborhoods with an excess amount of brownfields tend to be impoverished neighborhoods. ${ }^{5}$

2 Paul M. Sherer, “The Benefits of Parks: Why America Needs More City Parks and Open Space," The Trust for Public Land, 2003, 6, accessed February 10, 2014, http://www.eastshorepark.org/benefits_of_parks\%20tpl.pdf.

3 David Adams et al., "Mind the Gap! Taxes, Subsidies and the Behavior of Brownfield Owners," Land Use Policy 17 (2000): 135. 4 City of San José, Envision San José 2040 General Plan, August 2007, accessed February 20, 2014, http://www.sanjoseca.gov DocumentCenter/Home/View/474.

5 Thomas E. Deller, Bill Floriano, and Kristi Rea, "Vacant Lots," accessed March 12, 2013, http://www.brown.edu/Research/ EnvStudies_Theses/summit/Briefing_Papers/Vacant_Lots/index.html. 
Although brownfield sites can be detrimental to the community and the city's social health, they can also be seen as an opportunity. Brownfields are valuable resources since they can be prime sites for development. For instance, they can be developed into parks and playgrounds, urban farms or community gardens, commercial shopping centers, residential development, or schools, depending on the neighborhood's needs and site location. However, this project's specific aim is to address the issues that prevent this potential land from being converted into recreational open space or a linear park.

Land contamination is a great concern for urban residents. Urban soil (especially on former industrial lands) usually carries a considerable amount of heavy metal contamination. Lead, mercury, cadmium, and arsenic have caused serious health problems for human in different parts of the world. ${ }^{6}$ After abandoning the railroad corridors, railroad operations left some contaminants on those sites. The major contaminant sources are from materials used by industries located immediately adjacent to railroad beds and contaminants related to railroad management and operations such as herbicides or materials spilled from railroad accidents. However, the most common residual contaminations on railroad beds are arsenic, metals, and petroleum products. ${ }^{7}$ This can be extremely hazardous to the health of the adjacent residents, and it warrants an investigation prior to the onset of development. ${ }^{8}$

\section{Open Space is the Best Option}

The idea of turning abandoned railroad tracks into public open spaces is an environmental movement that started during the mid-1960s in the Midwest. Wherever railroads were removed, people started walking and biking on the right-of-way, using them as a transportation corridor. Since this movement has many benefits to environmental and physical health, it was accepted quickly and became popular all over the United States.

Open space corridors within urbanized areas offer many benefits for cities and their residents. Reusing abandoned railroad tracks support peoples' need for parks and green space and provides residents with recreational amenities. ${ }^{9}$ Land recycling can help preserve the natural environment, wildlife and habitat conservation, and improve air and water quality by reducing greenhouse emissions and decrease the amount of carbon dioxide. ${ }^{10}$ Linear parks can fill in the gaps in urban and suburban areas, and fight urban sprawl through providing a location for recreational activities.

6 T. C. Hutchinson and K. M. Meema, ed., Lead, Mercury, Cadmium and Arsenic in the Environment (Chichester, New York, Brisbane, Toronto: John Wiley \& Sons, 1987), 53.

7 Rails-To-Trails Conservancy, Understanding Environmental Contaminant: Lessons Learned and Guidance to Keep Your Rail- Trail

Project on Track, (Washington D.C.: TRAILDART, 2004), 5-6, accessed April 11, 2014, http://www.railstotrails.org/resources/

documents/resource_docs/EPAReport.pdf.

8 Wanxia Ren et al., "Inventorying Heavy Metal Pollution in Redeveloped Brownfield and Its Policy Contribution: Case Study from Tiexi District, Shenyang, China." Land Use Policy 38 (2014): 138-146.

9 Katherine Crewe, "Linear Parks and Urban Neighborhoods: A Study of the Crime Impact of the Boston South-west Corridor," Journal of Urban Design 6, no. 3, (2001): 245.

10 Center for Creative Land Recycling, "California's Brownfield Regulatory Agencies: Are all Cleanups Created Equal?"

(San Francisco: Center for Creative Land Recycling, 2006), 3. 
Open space corridors connect people, neighborhoods, and major land uses. ${ }^{11}$ Moreover, neighborhood gardens and open spaces increase residents' sense of community, build leadership, connect people to nature, and provide a physical place for the communities to focus their activities. This results in ownership and stewardship throughout the community and connects people from diverse cultures. In addition, green spaces in neighborhoods boost the economy of the area by having a direct influence on the property prices. Green space corridors can add another alternative for non-motorized transportation for residents' daily commutes such as walking or biking.

Spartan Keyes is an underserved neighborhood. The majority of residents are of the working class and the neighborhood itself suffers from a lack of parks and open spaces. The neighborhood benefits from different fund sources. The City's Park Trust has \$1.3 million to invest in Spartan Keyes. On the other hand park fees on new housing developments in the neighborhood can also contribute to parks and open space funding. ${ }^{12}$ Neighborhood leaders believe that this parcel is the best match for spending the neighborhood's funding to build a linear park. However, City officials are not in favor of this idea; their opinion is that the land cannot be turned into a park just because it is available. In addition to the cost of purchasing and remediating the land, authorities also argued about complications related to linear park's safety and access. ${ }^{13}$

\section{Methodological Overview}

In order to answer the research question, this study uses multiple methods for gathering data and conducting analysis. The first research method is documenting direct observations made of the case study site in order to understand the current condition of the brownfield parcel in the Spartan Keyes neighborhood. This audit has helped the author to learn about the existing physical condition of the parcel, and the infrastructure of the site's location. In-depth research has provided information about existing policies for brownfield redevelopment and remediation methodologies, in order to find the most effective method of remediation based on its future use as an open space. Moreover, this report represents the most efficient design guidelines that address safety for future use of the parcel as a linear park. At the end, a visual simulation of future use of the site is presented in a conceptual design of proposed redevelopment for the brownfield site based on Spartan Keyes leaders' input.

11 Center for Creative Land Recycling, "California’s Brownfield Regulatory Agencies: Are all Cleanups Created Equal?” (San Francisco: Center for Creative Land Recycling, 2006), 3. 12 Neighborhood Assessment and Community Engagement: Spartan Keyes (San José, CA: Urban Planning at San José State University, 2013), 56, accessed April 5, 2014, http://www.sjsu.edu/urbanplanning/docs/SpartanKeyesCommunityAssessment.pdf. 13 Interview with Spartan Keyes Neighborhood Action Leaders, September 10, 2014. 


\section{Report Structure}

Chapter two provides an overview of the Spartan Keyes neighborhood and the case study of the abandoned railroad parcel. This chapter also details the existing condition of the neighborhood and the abandoned parcel including the author's findings from site audits and maps.

Chapter three provides a broad understanding of brownfields and their redevelopment strategies. This chapter also explores the existing brownfield revitalization programs as well as remediation process and cleanup methods and the major challenges and benefits of brownfield redevelopment.

Chapter four presents successful stories of brownfield redevelopments and methods used for converting brownfields into linear parks.

Chapter five presents different design guidlines to address safety for linear parks and open space development. This chapter discusses the standard urban design guidelines that can help to ensure the future safety of open space at the brownfield site. The two concepts of Crime Prevention through Environmental Design (CPTED) and "Responsive Environments" are introduced and illustrated with hand-drawn sketches in this chapter.

The final chapter contains findings from the reaserch and the recomendations for the converting the abandoned brownfield site in the Spartan Keyes neighborhood into an open space. 


\section{Chapter 2: Existing Conditions in the Spartan Keyes Neighborhood}

\section{Overview of the Neighborhood}

The Spartan Keyes neighborhood, located approximately one mile south of the San José State University main campus, is one of the historical neighborhoods in central San José. Figure 1 illustrates the major road and landmarks in the neighborhood. There is also a concentration of automobile services in the neighborhood along Keyes Street.

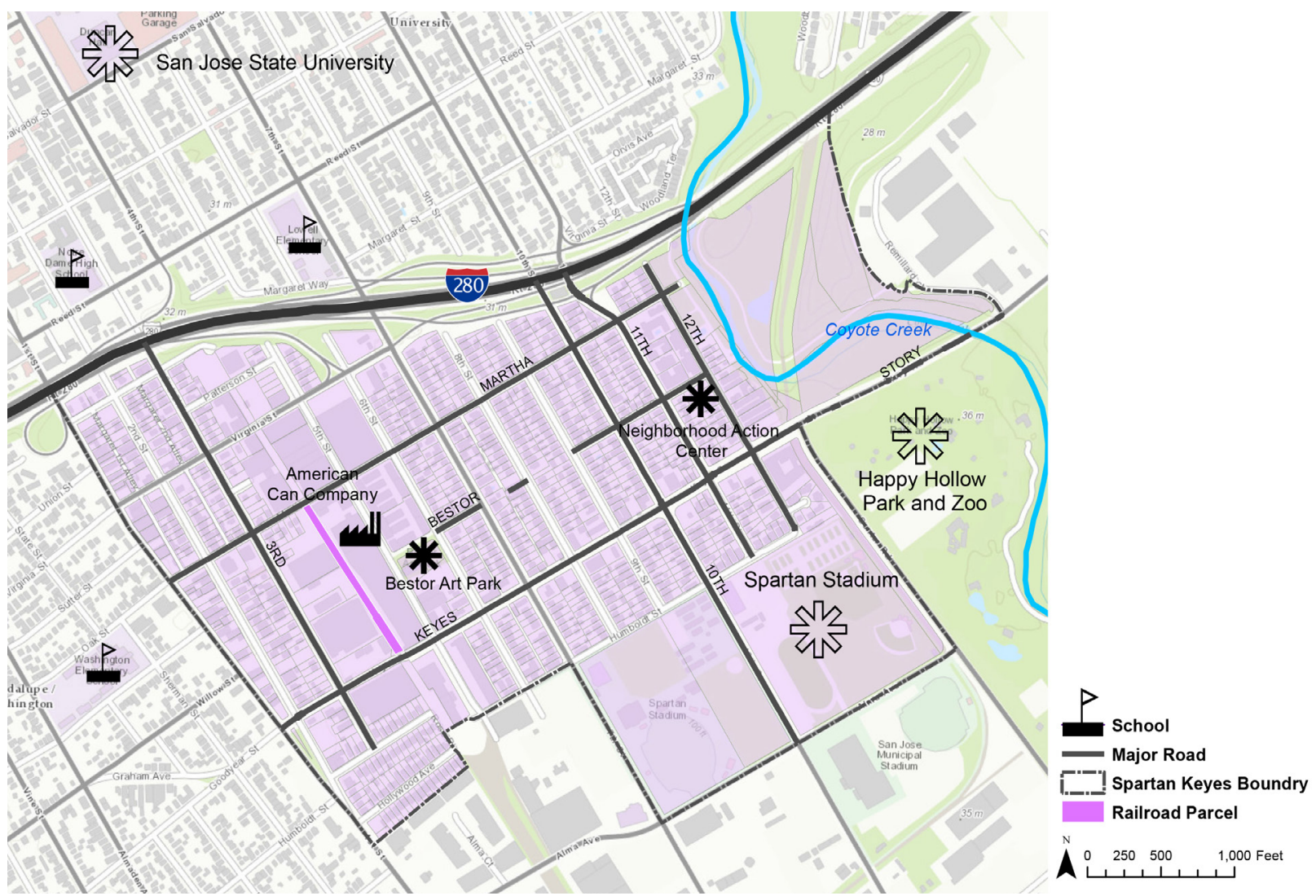

Figure1 Map of Roads and Landmarks in Spartan Keyes

Source: Author created map using data from ESRI Base Map, and Shapefiles from the the City of San Jose GIS database. 
The zoning map in Figure 2 shows that the entire neighborhood is affected by multiple light and heavy industrial zoning districts. The neighborhood lacks pedestrian-oriented facilities and neighborhood-scaled parks. Parks and open spaces cover $17 \%$ of the neighborhood's area. Yet, 0.7 -acre Bestor Art Park is the only park that serves Spartan Keyes residents. Coyote Creek flows on the east side of the neighborhood offers a good opportunity for open space. However, like Figure 3 shows, the area currently is occupied by a homeless encampment. Therefore, creating more open space that addresses residents' need for more greenery and community destination is a top priority for the Spartan Keyes neighborhood. ${ }^{14}$

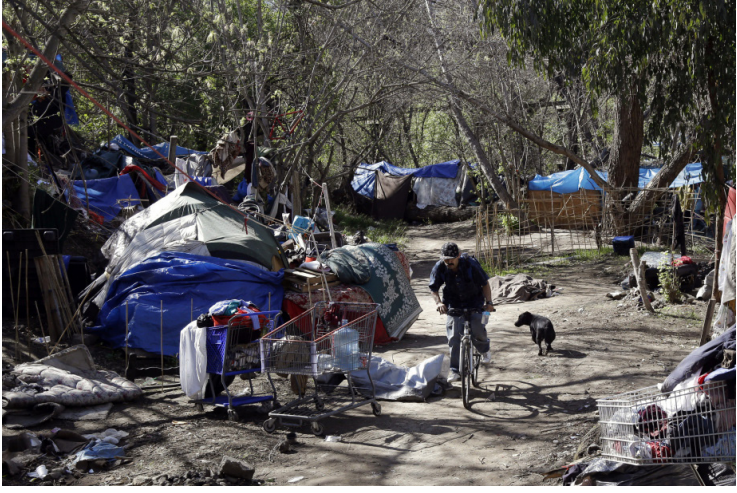

Figure 3 Homeless Encampment Along Coyote Creek

Source: "Program in Silicon Valley lifts some longtime destitute out of the Jungle," Portland Press Herald, accessed October 11, 2014, http://www.pressherald. com/2014/07/06/pr ogram-in-silicon-valley-lifts-somelongtime- destitute-out-of-the-jungle/.

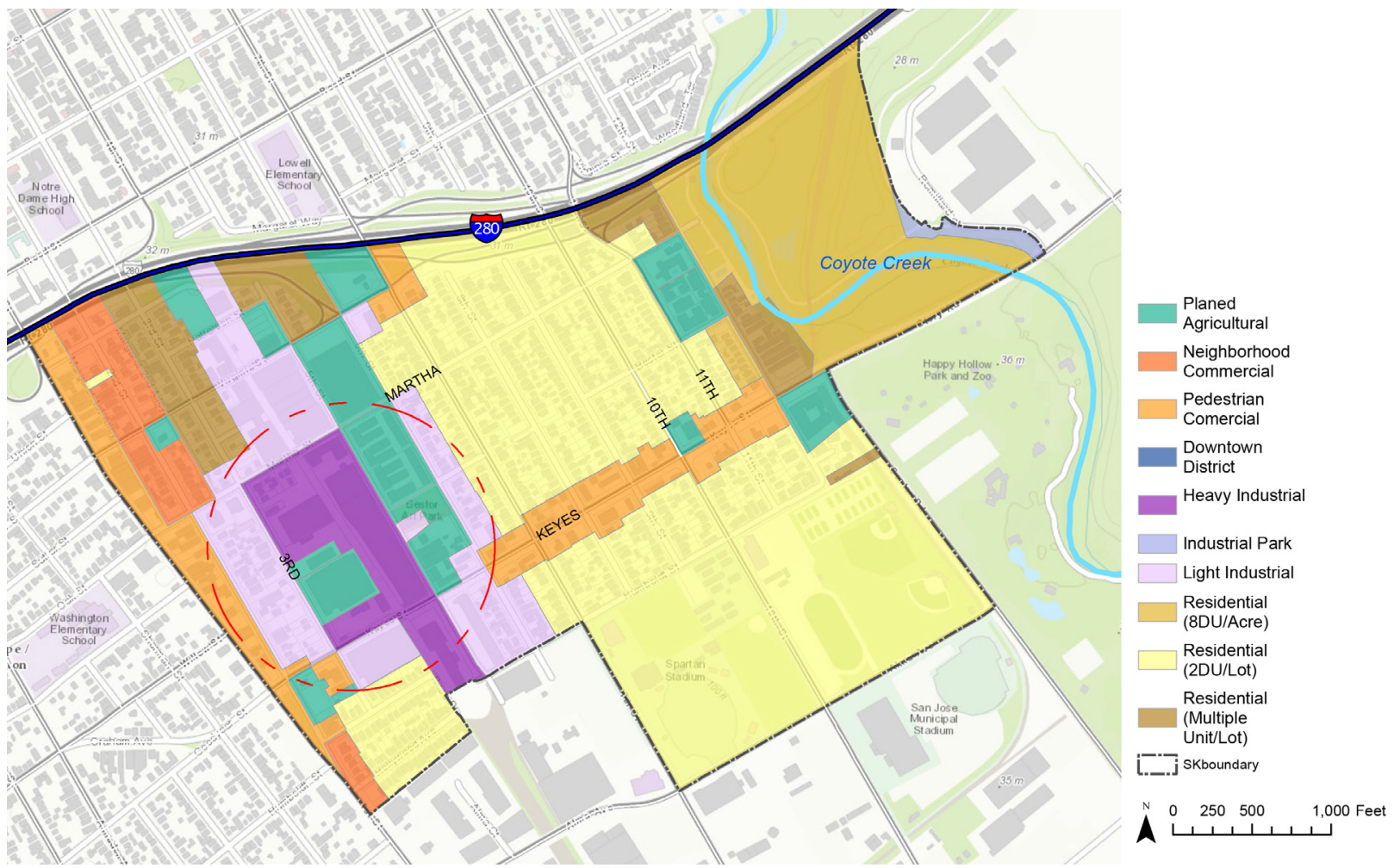

Figure 2 Zoning Map of Spartan Keyes

Source: Author created map using data from ESRI Base Map, Shapefiles from the the City of San Jose GIS database, and Graduate Student Community Assessment team (2012).

14 City of San José, Strong Neighborhood Initiative, Spartan Keyes: Neighborhood Improvement Plan Amendment, (San José, CA: City of San José, 2008), 9-54, accessed February 11, 2014, http://www.publicvisionresearch.com/community/Spartan_Keyes.pdf. 
Spartan Keyes land use map in Figure 4 shows has a broad variety of housing including singlefamily homes, duplexes, multifamily apartments, and condominium housing. However, the overall neighborhood's dominating land uses consist of artist studios, automobile businesses, and industrial warehouses. Figure 5 shows one the automobile businesses along Keyes Street.Various architectural styles of buildings date back to the 1930s. With the shortage in housing stock, multi-family residential development has been a new trend in the neighborhood. Even some large single-family Victorian houses have been converted to multiple-

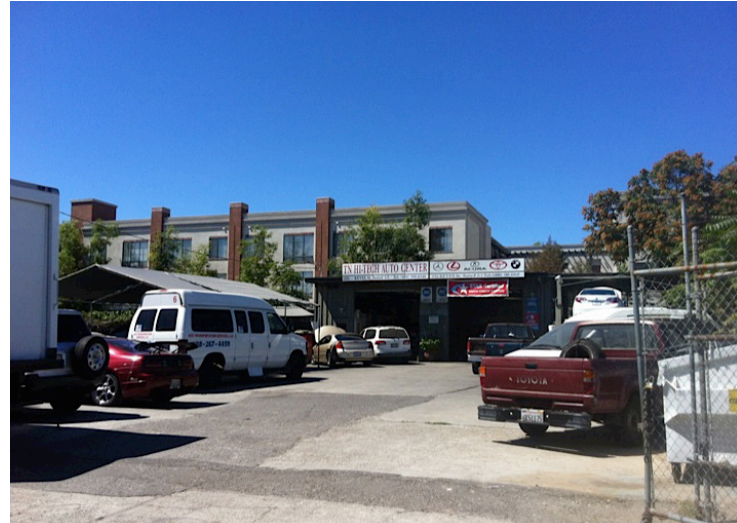

Figure 5 Auto Body Shop on Keyes Streeet Source: Photograph by Author. family residential dwellings. ${ }^{15}$ In addition, there are a considerable number of warehouses and buildings with light industrial use that can be seen as a potential for the future redevelopment or use conversion.
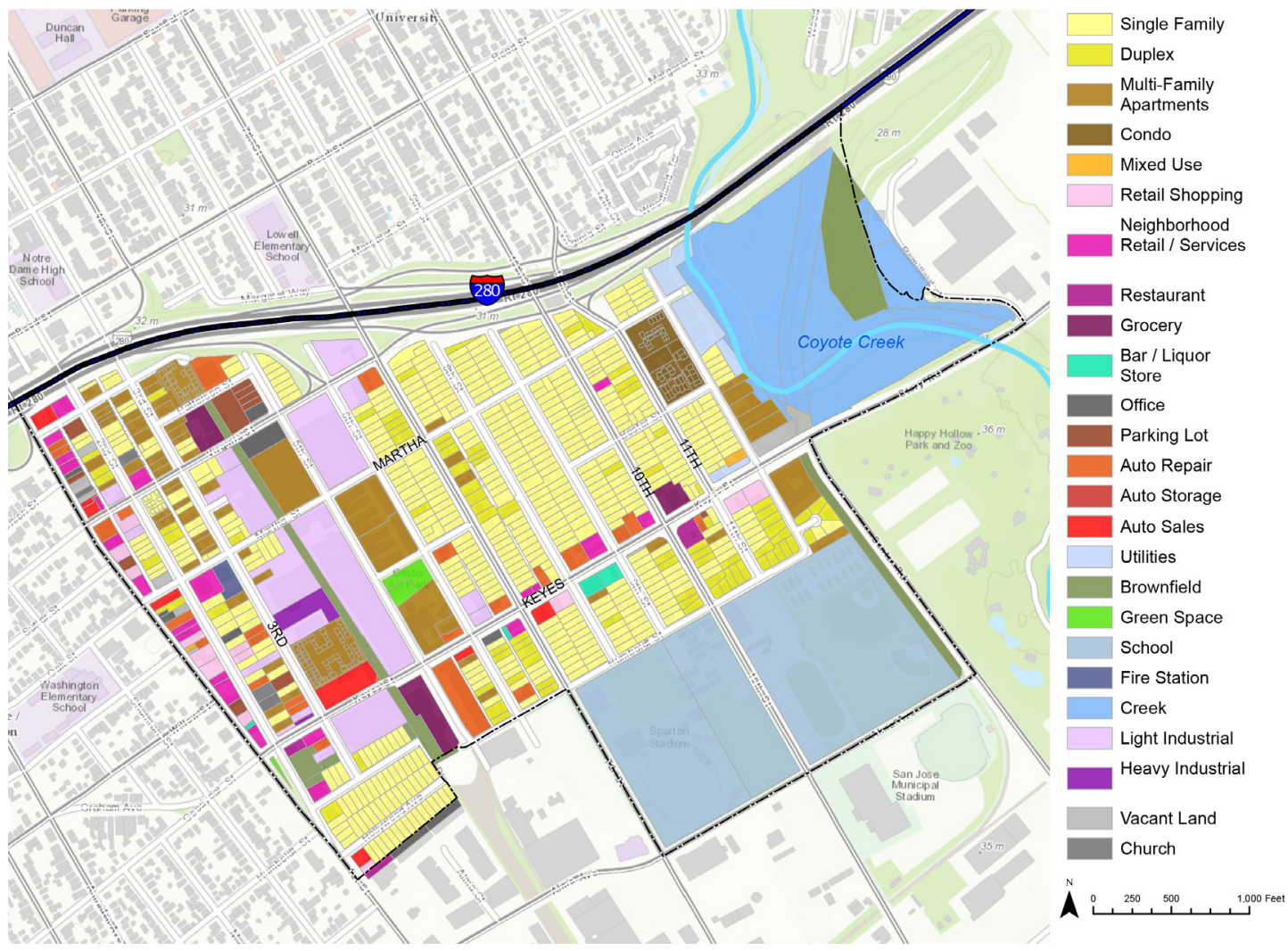

Figure 4 Land Use Map of Spartan Keyes

Source: Author created map using data from ESRI Base Map, Shapefiles from the the City of San Jose GIS database, and Graduate Student Community Assessment team (2012).

15 City of San José, Strong Neighborhood Initiative, Spartan Keyes: Neighborhood Improvement Plan Amendment, (San José, CA: City of San José, 2008), 40-1, accessed February 11,2014, http://www.publicvisionresearch.com/community/Spartan_Keyes.pdf. 
The Spartan Keyes neighborhood lacks gathering destinations for its residents. There is no permanent neighborhood center. The current Neighborhood Action Center is leased from a local affordable apartment complex. The Bestor Art Park, shown in Figure 6 is the only neighborhood-scaled park that offers a centralized gathering place. Residents have identified shortages in some neighborhoodserving businesses such as coffee shops, restaurants, and markets. A new neighborhood destination provides an activity place for children, specially those who go to one of three different elementary schools beyond the neighborhood's boundaries, and their parents. ${ }^{16}$

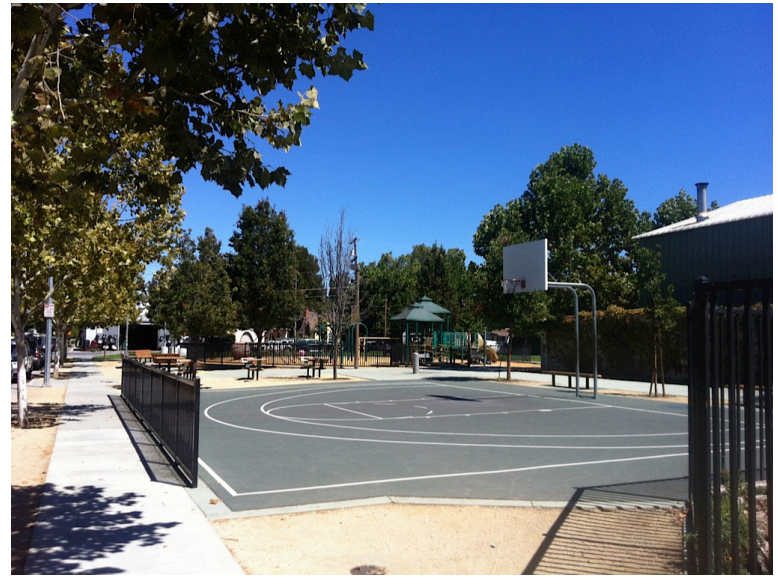

Figure 6 Bestor Art Park

Source: Photograph by Author.

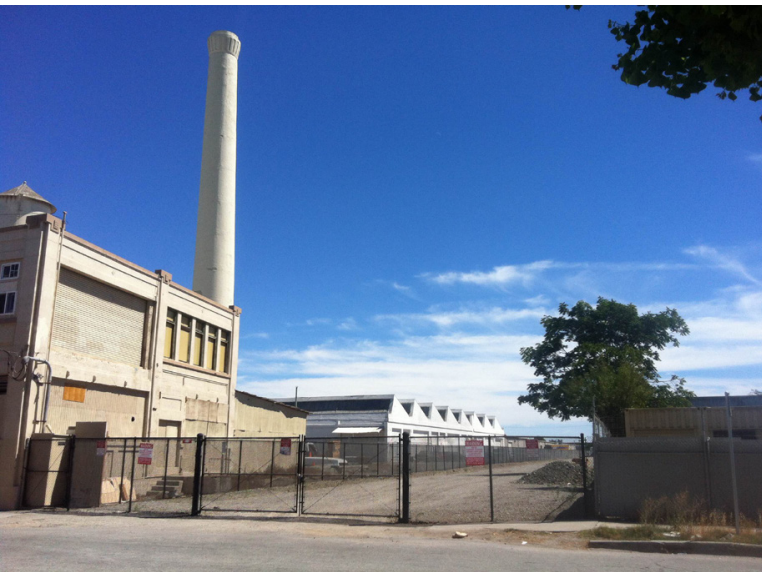

Figure 7 American Can Company and 4th Street Line, View from Martha Street

Source: Photograph by Author. chain- link fence.

16 Neighborhood Assessment and Community Engagement: Spartan Keyes (San José, CA: Urban Planning at San José State University, 2013), 46-7, accessed April 5, 2014, http://www.sjsu.edu/urbanplanning/docs/SpartanKeyesCommunityAssessment.pdf. 17 Joseph Belmont, "Abandoned Rails of San José," accessed May 12, 2013, http://www.abandonedrails.com/San_Jose California. 18 City of San José, Memorandum, Spartan Keyes SNI Neighborhood Improvement Plan Amendment, accessed May 7, 2014, http:// planning.sanjoseca.gov//planning/hearings/PC/2008/REPORTS/11-05/8b_SNI_SK.pdf. 
It has been almost three years since the residents of the Spartan Keyes neighborhood have tried to solve the longterm issue of the vacant parcel next to the American Can Company. ${ }^{19}$ According to the zoning map in Figure 2, this vacant linear site is presently zoned for heavy industrial uses by the City of San José. ${ }^{20}$ Community members and city officials had discussed several times about potential park locations. Aurelia Sanchez, resident and neighborhood activist, believes that the former rail line is an ideal site for a linear park. The land is privately owned and currently on the market for one million dollars. ${ }^{21}$ This narrow shaped parcel is approximately one acre in size and

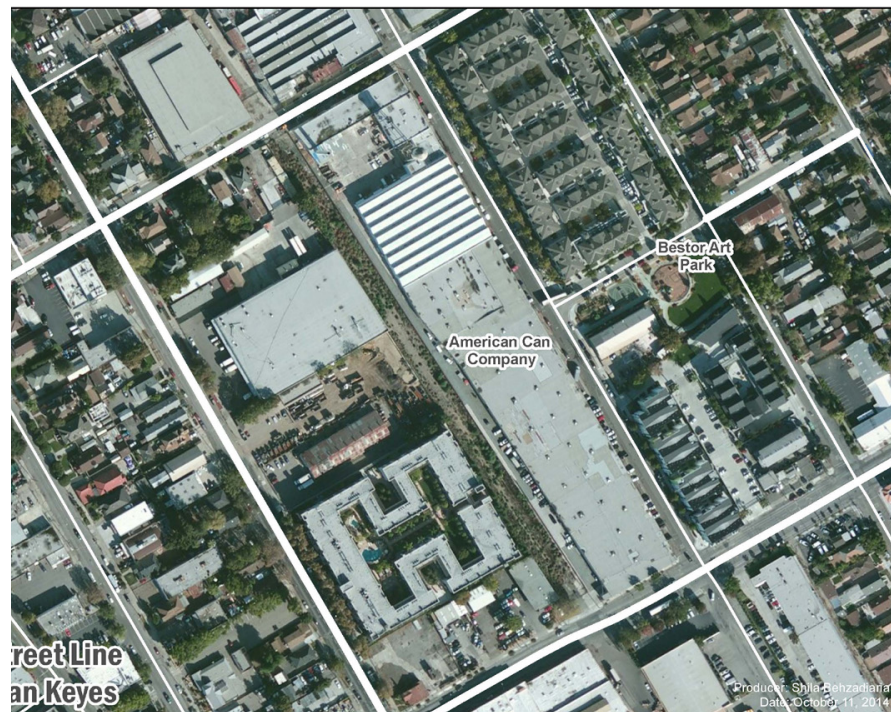

Figure 8 Aerial View of 4th Street Line

Source: Author created map using data from ESRI Base Map. is located between light industrial uses and residential buildings.

The community's strong desire for that property to be purchased for future park use has been expressed to Councilmember Sam Liccardo and the Deputy Director of the Parks, Recreation and Neighborhood Services Department, Matt Cano. However, both Liccardo and Cano have discouraged the community from putting further effort into this particular site. Since the parcel used to be Union Pacific Railroad right-of-way, it has potential environmental safety concerns. The parcel is a brownfield that is contaminated with heavy metal pollution. ${ }^{22}$

Moreover, the former railroad site does not have "key qualities of a park". According to Matt Cano there are several items that qualify a site to be developed as a park: $:^{23}$

- Safety: parks should be safe and inviting, provide good sightlines

- Access: parks should provide multiple entrances and exits

- Size: parks should be large and geographically separated to serve a large group of people

- Use: potential park's uses and purpose must be considered in advance before purchasing the land

19 Rita Torres, e-mail to author, November 24, 2014.

20 City of San José, Strong Neighborhood Initiative, Spartan Keyes: Neighborhood Improvement Plan Amendment, December 2 , 2008, 9, accessed February 11, 2014, http://www.publicvisionresearch.com/community/Spartan_Keyes.pdf.

21 Neighborhood Assessment and Community Engagement: Spartan Keyes (San José, CA: Urban Planning at San José State University, 2013), 56, accessed April 5, 2014, http://www.sjsu.edu/urbanplanning/docs/SpartanKeyesCommunityAssessment.pdf. 22 Ibid.

23 Rita Torres, e-mail to author, August 22, 2013. 
Regarding the above-mentioned items, the parcel is isolated from the community by surrounding industrial and residential buildings, and it has limited access from the street. The parcel is not inviting and people driving by may not know it is a public green space. There are not enough buildings facing the 4 th Street Line in order to provide a safe atmosphere. The city chooses park sites based on the purpose they are trying to achieve, such as a trail or large open area for sports. Although Figure 9 shows the majority of the neighborhood falls into the walking distance (10 to 15 minutes) service area, the Park Department authorities believe that the size of this parcel limits the potential use of a park. The site is also located within walking distance from Bestor Art Park. Although converting this parcel into a park can be beneficial for the community, it would be serving the same people who already use Bestor Art Park. Therefore, the City is reluctant to spend available funds allocated to Spartan Keyes on a site that is not ideal. ${ }^{24}$

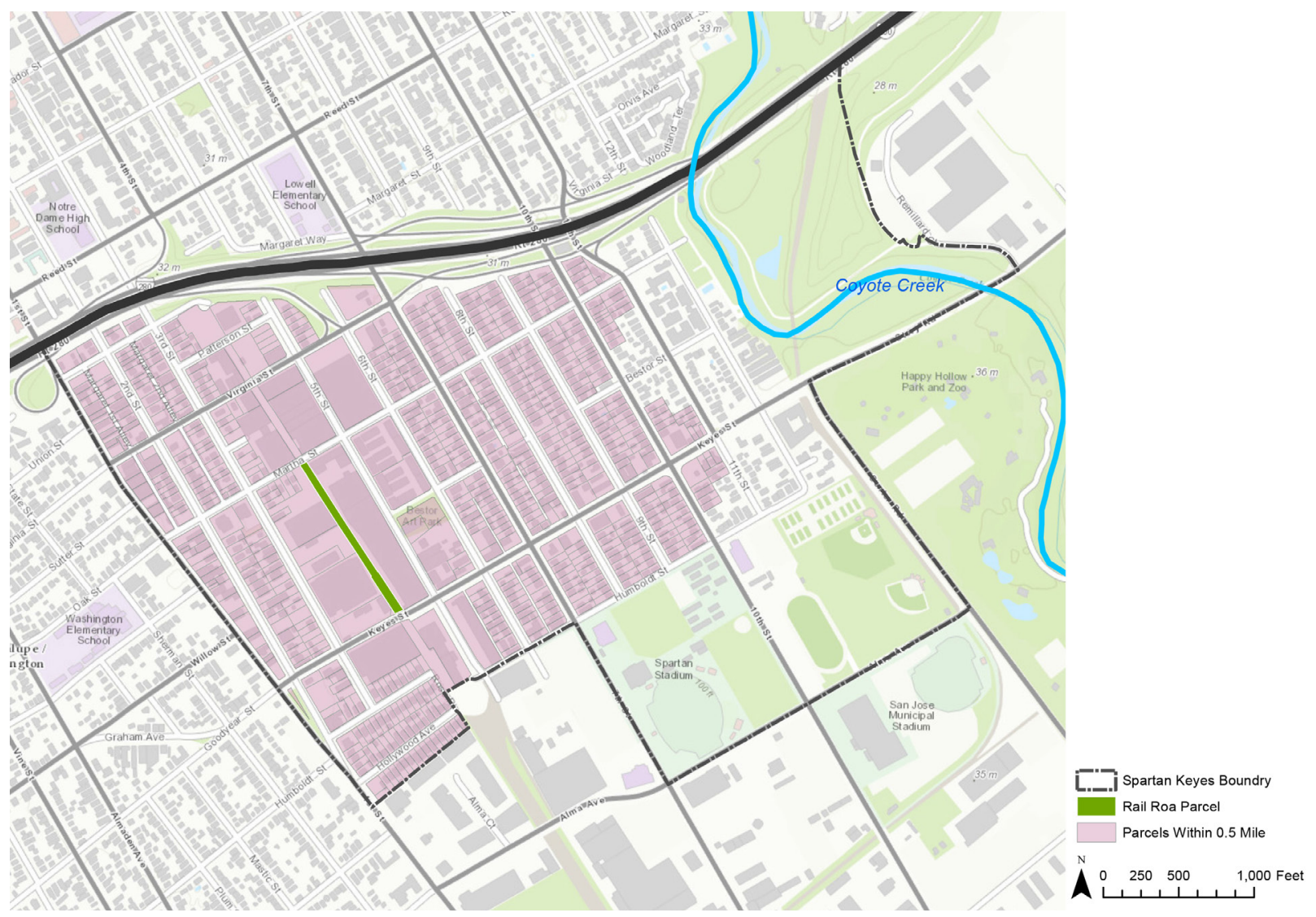

Figure 9 Service Area Map of 4th Street Line in 10 to 15 Minutes Walking Distance

Source: Author created map using data from ESRI Base Map, and Shapefiles from the the City of San Jose GIS database.

24 Neighborhood Assessment and Community Engagement: Spartan Keyes (San José, CA: Urban Planning at San José State University, 2013), 57, accessed April 5, 2014, http://www.sjsu.edu/urbanplanning/docs/SpartanKeyesCommunityAssessment.pdf. 


\section{Chapter 3: Pollution Concerns}

\section{What is a Brownfield?}

The United States Environmental Protection Agency (EPA) defines a brownfield as a property in which any redevelopment can be hazardous due to the existence of a contaminant substance. ${ }^{25}$ In general any type of land that had a previous use or had been developed but currently is underutilized is a brownfield. The land could be vacant, contaminated, or contain derelict buildings, and in all cases is not ready for immediate use because needs to be remediated first. ${ }^{26}$

The redevelopment of brownfields depends on many criteria such as ownership, location, parcel shape and size. The process of brownfield redevelopment is not an easy one and usually faces many social, legal, and economic obstacles. Developing on contaminated land is very controversial. First, the level of contamination must be determined; depending on the future use of the land, the cleanup standards and cost of the remediation may differ. ${ }^{27}$ The type and the level of contamination are the main criteria that impact the intended redevelopment use. ${ }^{28}$

\section{Revitalization Programs}

There are different approaches for brownfield redevelopment based on the level of contamination and the future use of the redevelopment site. The Comprehensive Environmental Response, Compensation and Liability Act (CERCLA), commonly known as a Superfund, mainly focuses on the remediation of severely contaminated hazardous waste sites, such as chemical and petroleum industries which have been identified and listed under federal EPA. ${ }^{29}$ This cleanup approach is compared with a more relaxed risk-based approach called Voluntary Cleanup Program (VCP). VCP remediation strategies are based on safety, cost effectiveness, and risk- based management and allow contaminants to remain on site as much as possible. This is because many land owners or developers do not want to risk extreme cleanup costs that sometimes may exceed the land's price, and it is assumed that the level of property's contamination is not sufficient to qualify under superfund program. ${ }^{30}$

25 "Land and Cleanup," US Environmental Protection Agency, last modified January 15, 2014, accessed February 22, 2014. http://www2.epa.gov/regulatory-information-topic/land-and-cleanup\#brown.

26 Sandra Alker et al., "The definition of brownfield," Journal of Environmental Planning and Management 40, no.1 (2000): 50. 27 "Brownfields Health \& Safety for Sites Evaluated \& Remediated under Federal Brownfields Initiatives or State Voluntary Cleanup Programs," US Department of Labor, accessed February 22, 2014, https://www.osha.gov/SLTC/brownfields/brnfld_qna.html. 28 Richard C. Hula, and Rebecca Bromley-Trujillo, “Cleaning Up the Mess: Redevelopment of Urban Brownfields," Economic Development Quarterly 24 (2010): 277.

29 US Environmental Protection Agency, Brownfields and Land Revitalization, accessed March 20, 2014, http://cfpub.epa.gov/ bf_factsheets/gfs/index.cfm?xpg_id=7927\&display_type=HTML.

30 G. William Page, and Robert S. Berger, "Property Characteristics of Contaminated Land in Environmental Cleanup Programs in New York State," Public Works Management Policy 10 (2005): 158-161. 
VCPs encourage revitalization of contaminated properties by the following policies: ${ }^{31}$

- Modifying the cleanup standards to the intended future use level

- Providing financial incentives to motivate investment in contaminated sites

- Providing regulatory control and guidance for site maintenance

- Offering liability release based on state's approval of cleanup level

- Handing state regulatory functions over to the private sector

If a brownfield is not on the federal priority list, or identified as a Superfund site, the EPA does not have a regulatory clean-up actions. ${ }^{32}$ Agencies, such as the EPA Brownfields Program, allow states, communities, and other stakeholders to work together to redevelop the economy, clean up, and sustainably reuse brownfields. ${ }^{33}$ EPA's brownfield program offers different types of grants and modifies policies to protect land owners from CERCLA liability. ${ }^{34}$ EPA's requirements in cleanup activities are different for each state. ${ }^{35}$

\section{Revitalization Challenges}

Communities that want to redevelop their brownfields usually face many challenges. These challenges are found throughout the entire redevelopment process, from purchasing the land to managing the obstacles that brownfield redevelopment inevitably faces. ${ }^{36}$

The difficulty of brownfield redevelopment must be considered, along with the costs of doing nothing, which can be harmful because contaminants are hazardous to human health and environmental. ${ }^{37}$ Therefore, before recommending any solutions for the remediation of contaminated land, it is critical to know the type and level of contamination to estimate the time and the budget for cleaning the contamination. ${ }^{38}$ Therefore, vague or high cleanup costs are the most common challenge in brownfield redevelopment projects, followed by liability.

31 Kris, Wernstedt, et al, "Revitalizing Underperforming and Contaminated Land through Voluntary Action: Perspectives from U.S. Voluntary Cleanup Programs," Land Use Policy 31 (2013): 546.

32 Ibid.

33 "Brownfields and Land Revitalization," US Environmental Protection Agency, last modified July 16, 2012, accessed February 22, 2014, http://www.epa.gov/brownfields/basic_info.htm.

34 “The Brownfield Program: Setting Change in Motion,” US Environmental Protecting Agency, 2002, accessed April 22, 2014, https://play.google.com/books/reader?id=O0jfrK986ykC\&printsec=frontcover\&output=reader\&authuser=0\&hl=en\&pg=GBS . PT1.

35 Kris, Wernstedt, 548.

36 Rails-To-Trails Conservancy, Understanding Environmental Contaminant: Lessons Learned and Guidance to Keep Your Rail- 
Owner's liability has three key aspects. The first aspect is the level of contaminant concentration on the site; the second aspect is the potential health issues caused by proximity to the contaminant or contaminants; and the third aspect is anything that makes the owner liable in a court of law..$^{39}$ The liability protection from third-party claims was the most important liability protection that the state VCP offers, presumably because it most affects the return on investment. The remaining respondents were split roughly equally between protections from liability for additional existing contamination that might be discovered in the future and liability for changes in standards. ${ }^{40}$
Table 1 Brownfield Revitalization Challenges

\begin{tabular}{|l|l|}
\hline \multirow{5}{*}{ Opposition, Fear of gangs, crime, and homeless encampments } \\
\hline \multirow{5}{*}{ Revitalization } & Sale price of the land \\
\hline & Municipal priorities \\
\hline & Project duration \\
\hline & Neighborhood social and physical features \\
\cline { 2 - 3 } & Feeble brownfield management \\
\hline & Lack of sustainable clean up method \\
\hline & Potential of hesitancy to sell from land owner \\
\hline & Kicked-up dust from construction \\
\hline & Technical difficulties in assessing the level of contamination \\
\hline & Vague cleanup costs \\
\hline & Bureaucratic/ procedural processes \\
\hline & Liability \\
\hline Restrictive zoning \\
\hline Lack of political will \\
\hline
\end{tabular}

Source: Sichley (2013), De Sousa (2006), De Sousa (2005), Nijkamp (2002), Hula (2010) Schwarz (2009), and Bowen (2006).

The identified main challenges for developers consist of vague cleanup costs, liability, project duration, and lack of funding sources and sustainable clean up method. ${ }^{41}$ Limited available financial support, the bureaucratic processes involved, and technical difficulties in assessing the extent of contamination are all among challenges of brownfield redevelopment. ${ }^{42}$ Table 1 summarizes the challenges of brownfield revitalization.

\section{Revitalization Benefits}

The remediation and redevelopment of brownfields has several social, environmental, and economic benefits for people and their communities. For example, clean-ups can generate new jobs and higher tax revenues; therefore, many communities, business owners, and

39 Edwin K. L. Tam, and Philip H. Byer, "Remediation of Contaminated Lands: A Decision Methodology for Site Owners," Journal of Environmental Management 64 (2002): 388.

40 Kris, Wernstedt, 549.

41 Christopher De Sousa, "Urban Brownfields Redevelopment in Canada: The Role of Local Government," The Canadian Geographer / Le G'eographe canadien 50, no. 3 (2006): 395.

42 Christopher, De Sousa, "Policy Performance and Brownfield Redevelopment in Milwaukee, Wisconsin," The Professional Geographer 57, 2 (2005): 318. 
environmentalists have supported brownfield revitalization. ${ }^{43}$ Remediation and redevelopment of such land can improve environmental and human health by cleaning up contamination, and improves the local economy by constructing new residential buildings and parks, developing commercial amenities, and providing new job opportunities. ${ }^{44}$

The redevelopment of abandoned railroad beds into open spaces is initiated once people start using them as a walking path. Therefore, one major benefit of redeveloping brownfields is using these sites as an infrastructure for non-motorized transportation. Linear open space can help in linking land to other trails, other geographical locations, or major activity centers and result in increasing land value in the surrounding neighborhood after the trail's construction..$^{45}$
Table 2 Brownfield Revitalization Benefits

\begin{tabular}{|c|l|}
\hline \multirow{5}{*}{ Revitalization } & Increase in local economy improvement \\
\cline { 2 - 2 } Benefits & Increasing land and adjacent properties' value \\
\cline { 2 - 3 } & Supports communities recreational need \\
\cline { 2 - 3 } & Supports communities recreational need \\
\cline { 2 - 3 } & Reduction in undesirable activities such as dumping and crime \\
\cline { 2 - 3 } & Infrastructure improvement \\
\cline { 2 - 3 } & Regional connectivity \\
\cline { 2 - 3 } & Connection people and communities \\
\cline { 2 - 3 } & Economic growth \\
\cline { 2 - 3 } & Environmental protection \\
\cline { 2 - 3 } & Recreation opportunities \\
\cline { 2 - 3 } & Urban renewal \\
\cline { 2 - 3 } & Generating employment \\
\hline & Reduction of physical and environmental hazard \\
\hline & Reduction of urban sprawl \\
\hline
\end{tabular}

Source: Sichley (2013), De Sousa (2006), De Sousa (2005), and Bowen (2006).

Urban revitalization is the key benefit of brownfield redevelopment as well as economic benefits such as an increase in the tax generation, increase in employment, and an increase in adjacent property values. Brownfield redevelopment also reduces urban sprawl and physical and environmental hazards. Social benefits of brownfield redevelopment include an increase in public space; new development opportunities; infrastructure improvements; and a reduction in undesirable activities such as dumping and crime. ${ }^{46}$ Take Trenton, New Jersey as an example, which interviews demonstrated environmental benefits associated with brownfields redevelopment, such as urban sprawl and traffic congestion reduction as well as social benefits

43 “Brownfields Center," Environmental Law Institute, accessed February 25, 2014, http://www.brownfieldscenter.org/big/bfbasics. shtml.

44 Ye Chen et al., “A Strategic Classification Support System for Brownfield Redevelopment," Environmental Modeling and Software 24 (2009): 647-8.

45 Dawn S. Bowen, "Building a Trail and Connecting a Community: The Establishment of the Dahlgren Railroad Heritage," Trail southeastern geographer, 49, no.3 (2009): 293. 
like increasing residents' awareness and sense of community from being part of the decision making process, reduced crime and improved safety and security. ${ }^{47}$

Investing in brownfields is highly influenced by economic factors, including the availability of grants, increasing the local tax base, taking advantage of business opportunities, and generating employment opportunities. In addition, crime elimination and liability reduction as social factors can streamline the brownfield redevelopment process. ${ }^{48}$ Table 2 , in the previous page, provides a list of brownfield redevelopment benefits.

\section{Policy Recommendation}

The brownfield redevelopment process can be streamlined through implementing several policy recommendations. The research shows that since the main challenges for developers consist of vague clean-up costs and limited available financial support, providing more funding through grants and subsidies is the most efficient policy to encourage brownfield redevelopment. Liability reduction, relaxed development standards, and efficient permitting process can help address the bureaucratic processes involved in brownfield redevelopment.

Table 3 Brownfield Revitalization Policy Recommendation

Educating residents the value of converting brownfields into green space is important. Therefore, community residents should get involved in the planning process. In addition to the education of residents, a partnership between residents and public authorities can also be used to streamline the redevelopment process. ${ }^{49}$ Table 3 provides a list of policy recommendation for brownfield redevelopment.

\begin{tabular}{|c|l|}
\hline \multirow{5}{*}{$\begin{array}{c}\text { Revitalization } \\
\text { Policy }\end{array}$} & Encouraging economic funds \\
\cline { 2 - 2 } & Neighborhood educating \\
\cline { 2 - 2 } & Lenders' involvement \\
\cline { 2 - 3 } & Understanding community interests \\
\cline { 2 - 3 } & Patience and flexibility \\
\cline { 2 - 3 } & Siability reduction \\
\cline { 2 - 3 } & Relax development standards \\
\cline { 2 - 3 } & Partnership between residents and the city officials \\
\cline { 2 - 3 } & Promote risk based assessment \\
\cline { 2 - 3 } & Enhancing funds and incentives \\
\cline { 2 - 3 } & Tax exempt redevelopment or tax-free financing \\
\cline { 2 - 3 } & Streamlining the permitting process \\
\cline { 2 - 3 } & Tax on unoccupied property \\
\cline { 2 - 3 } & Partnership with local government \\
\hline
\end{tabular}

Source: Sichley (2013), De Sousa (2006), De Sousa (2005), and Bowen (2006).

47 Jonathan P. Deason, George William Sherk, and Gary A. Carroll, Public Policies and Private Decisions Affecting the Redevelopment of Brownfields: An Analysis of Critical Factors, Relative Weights and Areal Differentials (Washington, DC : The George Washington University, 2001) accessed October 1, 2014, http://www.gwu.edu/ eem/Brownfields/project_report/chaptershtml.htm.

48 Christopher, De Sousa, "Policy Performance and Brownfield Redevelopment in Milwaukee, Wisconsin," The Professional Geographer 57, no. 2 (2005): 316.

49 Dawn S. Bowen, "Building a Trail and Connecting a Community: The Establishment of the Dahlgren Railroad Heritage," Trail southeastern geographer, 49, no.3 (2009): 303. 


\section{Remediation Process}

The first step in the remediation process is to investigate the type, source, and level of contamination by audits and any other documentation of previous land use. Next, field testing is required to determine the extent of contamination. Then, speed and direction of ground water and soil permeability should be tested. Finally, the surrounding nature, demographics, land uses need to be identified. Such circumstances determine the owner's liability because future users of the site after redevelopment may be at risk. For example, if the groundwater flows in the direction of the school and residential dwellings and the site has a permeable ground; therefore, the primary school and the houses are considered to be the owner's potential offsite liability. ${ }^{50}$

In California, the brownfield remediation project's advocate usually follows a three step framework: ${ }^{51}$

- Establish a set of screening levels, by referencing the appropriate regional U.S. EPA office

- Upgrade screening levels of first step based on agreed-upon, site-specific factors such as sand vs. clay, rainfall, anticipated users, and etc. (Remediation goals in this step are slightly less conservative than the first levels, yet equally protective)

- Calculate remediation goals for all contaminants through site-specific risk based analysis. (This process is only applied to the most complicated sites, and the final result could be more or less conservative than the defined level for that contaminant)

An environmental assessment must be conducted in order to redevelop a railroad bed into a linear space. The cost of an environmental assessment based on the property and the level of contamination can range from a few thousand dollars to over $\$ 20,000 .{ }^{52}$ Environmental assessment for estimating the level of contamination based on the audits and previous uses can go through three phases:

- Phase I: Investigate history of the property and visual inspection, examine historic aerial photographs, interview local government agencies and adjacent land owners

- Phase II: More intensive investigation, including the testing of water, soil, and air samples

- Phase III: Review of remediation alternatives and costs

However, a Phase I assessment, the least extensive of the three types of assessments, is typically performed for all projects. ${ }^{53}$

50 Edwin K. L. Tam, and Philip H. Byer, "Remediation of Contaminated Lands: A Decision Methodology for Site Owners," Journal of Environmental Management 64 (2002): 389.

51 Center for Creative Land Recycling, “California's Brownfield Regulatory Agencies: Are all Cleanups Created Equal?” (San Francisco: Center for Creative Land Recycling, 2006), 12.

52 Rails-To-Trails Conservancy, Understanding Environmental Contaminant: Lessons Learned and Guidance to Keep Your RailTrail Project on Track, (Washington D.C.: TRAILDART, 2004), 14, accessed April 11, 2014, http://www.railstotrails.org/resources/ documents/resource_docs/EPAReport.pdf. 


\section{Cleanup Methods}

Technologies for the remediation of contaminated lands usually require a large budget and the solutions are not always reliable. There are several methods for brownfield remediation. The most common remedial methods consist of: ${ }^{54}$

- Cut and fill: Removing high contaminated soil and replace it with clean soil. The removed soil should be dumped in a location that is not hazardous for humans and the environment. However, the soil can be recycled and reused in roadway subgrades, or, if the corridor is wide enough, it can be dumped in the site and covered by vegetation

- Capping the surface: Isolating contaminated soil with a hard surface such as asphalt or cement. Crushed stone also can be used with an appropriate depth

- Exclusions: For some highly contaminated corridors, parts of the trail that pose a higher risk can be isolated from human contact

- Signage and fencing: Protecting trail users from specific contaminated sites

- Phytoremediation: Using plants to clean contaminated soil or water

Due to strict federal policies, off-site disposal is the most popular method. However, removing the contaminated soil is not the best practice since this can be harmful to the health of adjacent residents as pollution gets dispersed. The extremely high cost of the cleanup and finding a safe location for dumping the polluted soil are other problems. ${ }^{55}$ Therefore, in the relaxed brownfield remediation strategies capping by utilization of soil, concrete or other materials is found to be the most common and cost-effective method..$^{56}$

A comparative study in 2006 has been done by The Center for Creative Land Recycling (CCLR), a nonprofit organization that helps in community improvements and supports urban sprawl prevention. The study reveals that environmentally distressed properties or "brownfields" in California have been managed by either the Department of Toxic Substance Control (DTSC) or a Regional Water Quality Control Board (Water Boards) within the California Environmental Protection Agency. ${ }^{57}$

54 Rails-To-Trails Conservancy, Understanding Environmental Contaminant: Lessons Learned and Guidance to Keep Your Rail- Trail Project on Track, (Washington D.C.: TRAILDART, 2004), 14-5, accessed April 11, 2014, http://www.railstotrails.org/ resources/documents/resource_docs/EPAReport.pdf.

55 V. Franzius, "Perspectives on the Remediation of Contaminated Land in Germany," Chemistry \&Industry 3 (2013): 505-508, quoted in Christie R. M. Teeuw, Varied Policy Of European Union States On Contaminated Lands (University of Hertfordshire, 1998), 191.

56 Christopher De Sousa, “Turning Brownfields into Green Space in the City of Toronto," Landscape and Urban Planning 62 (2003): 188.

57 Center for Creative Land Recycling, “California's Brownfield Regulatory Agencies: Are all Cleanups Created Equal?” (San Francisco: Center for Creative Land Recycling, 2006), 2. 
Brownfields that were supervised by the Water Boards are the sites that are primarily contaminated with petroleum hydrocarbons, while others that were managed by the Department of Toxic Substance Control (DTSC) are mainly the sites where soil contaminants include heavy metals and residual pesticides which are less-mobile contaminants such as pesticides, whereas to the Water Boards that are charged with protecting human health and the environment by preserving the state's water quality, mobile contaminants that threaten drinking water sources such as petroleum hydrocarbons and solvents pose a greater concern. ${ }^{58}$ Most of cleanup projects in the state of California and under supervision of DTSC, have chosen off-site disposal and the rest have used capping as the remediation method..$^{59}$

\section{Findings}

There are feasible methods for brownfield decontamination. The abandoned parcel in Spartan Keyes most likely does not have severe contamination subject to CERCLA because it is not listed on Superfund project sites on the EPA's website. ${ }^{60}$

The important criteria used in brownfield development assessment are pre- and postredevelopment land uses, level of contamination, history of the property, location, liability concerns, cost of remediation and incentives available for the redevelopment. These are identified in order to anticipate the most practical and cost effective redevelopment plan. The brownfield parcel in this study used to be a railroad track. In this case, "capping" can be a cost- effective decontamination strategy.

Brownfield developers must know that the contamination risk does not stop after remediation if the contaminated soil is not removed. If the remediation method is capping the surface, the soil must be supervised regular maintenance. As part of this maintenance program, asphalt must be replaced every fifteen years and crushed stone replaced every ten years. In addition, trail fences and signage should be continually kept in a state of good repair. ${ }^{61}$

58 Center for Creative Land Recycling, “California's Brownfield Regulatory Agencies: Are all Cleanups Created Equal?” (San Francisco: Center for Creative Land Recycling, 2006),9.

59 Ibid.

60 US Environmental Protection Agency, Cleanup sites in California, accessed April 4, 2014, http://www.epa.gov/region9/ cleanup/california.html. 


\title{
Chapter 4: Successful Stories
}

\author{
Grants for Remediation of the Contaminated Land \\ Doyle Street Greenway, Emeryville, California
}

\section{Background}

The Doyle Street Greenway is located on the east side of the San Francisco Bay in the city of Emeryville. The trail project is part of a city-wide Emeryville Brownfields Pilot Project. The goal of the project is to transform old industrial lands and brownfield sites into vibrant high tech commercial industries and livable communities by adding a 0.4 mile extension to the Santa Fe Railroad spur line that once served Emeryville and Berkeley. ${ }^{62}$ Figure 10 shows the part of the trail that has been remediated and turned into a green open space, and the part that is still under construction.

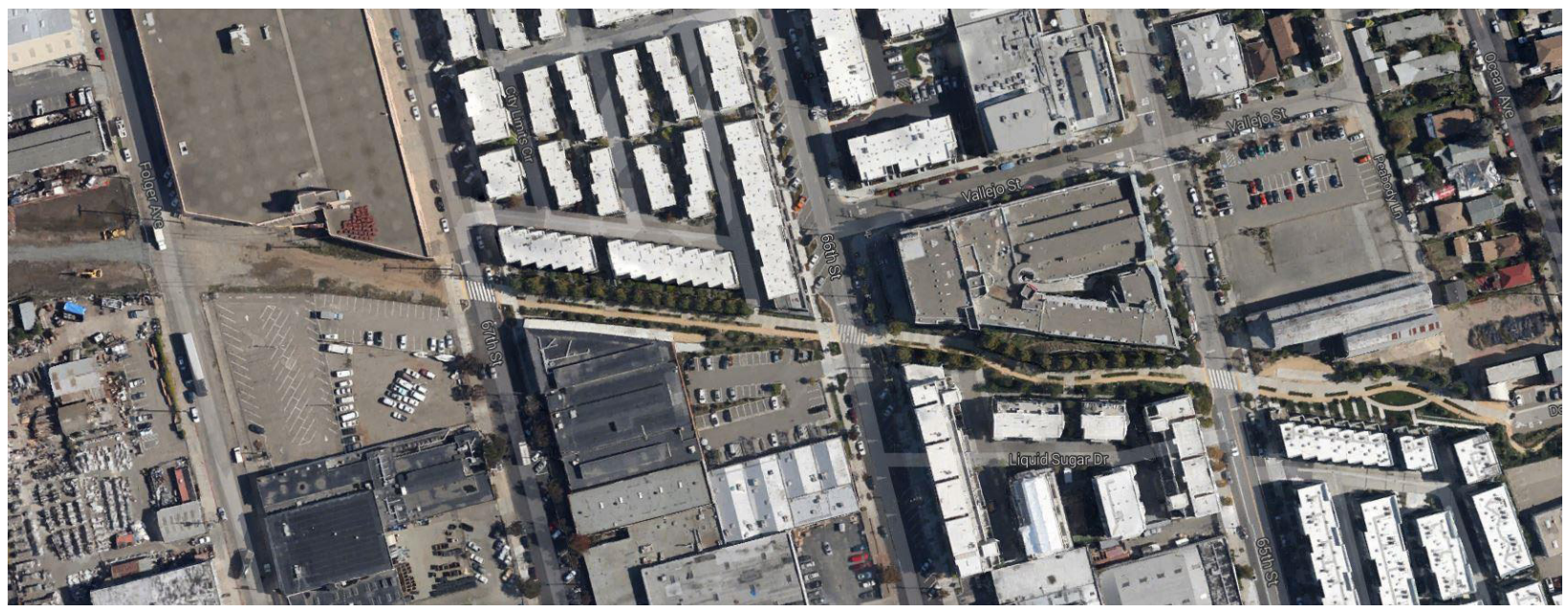

Figure 10 Aerial View of Doyle Street Greenway under Construction

Source: Google Maps, accessed October 12, 2014, https:/www.google.com/maps/

The corridor was tested for the presence of contamination before the city of Emeryville purchased the Union Pacific right-of-way. In order to learn about the size and the nature of contamination, both soil and ground water were tested. The soil samples showed a high level of metal contamination such as arsenic, lead, and petroleum hydrocarbons. The on-site observation determined that the area around the railroad was contaminated. ${ }^{63}$

62 Rails-To-Trails Conservancy, Understanding Environmental Contaminant: Lessons Learned and Guidance to Keep Your RailTrail Project on Track, (Washington D.C.: TRAILDART, 2004), 22, accessed April 11, 2014, http://www.railstotrails.org/resources/ documents/resource_docs/EPAReport.pdf.

63 Ibid. 


\section{Remediation Process}

The city of Emeryville, the U.S. Environmental Agency's (EPA) Department of Substances Control, the California EPA's Regional Water Quality Control Board and Union Pacific Railroad partnered together to help in the remediation process. EPA's Brownfield Assessment Department Pilot Program, the city of Emeryville, California State Park and Bicycle Bond Funds, and Union Pacific Railroad in collaboration funded the costs of the project which was roughly $\$ 1$ million. Pulte Homes, in Figure 10, is a private development company, which paid for the improvements adjacent to their housing projects. ${ }^{64}$

Off-site disposal was selected as the method for cleaning up the 2200 -foot rail site. Therefore, 2.5 feet of the entire site was removed and replaced by layer of hard surface and landscaping. The reasons for choosing this method were to provide a high level of protection for public health, and to reduce liability issues as well as long-term maintenance requirements. ${ }^{65}$

\section{Findings}

Many different factors, such as the acquisition of the land and risk assessment, impacted the cost of the project. Therefore, developing accurate cost

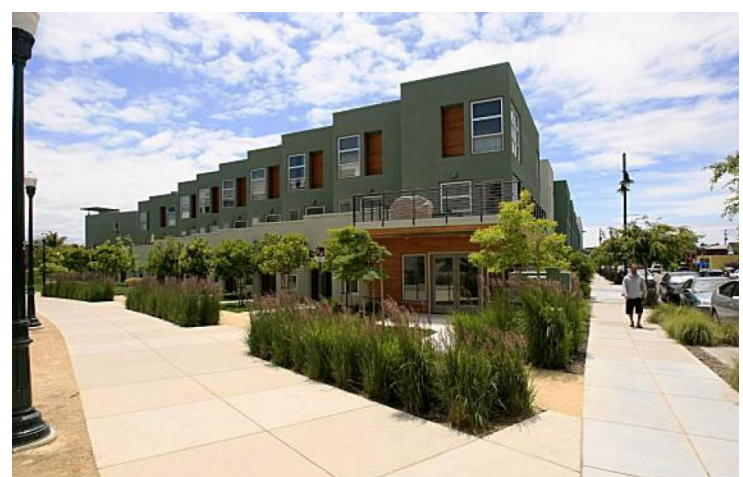

Figure 11 New Project Entrance to the Doyle Street Greenway

Source: SFGate, accessed October 10, 2014, http://www. sfgate.com/entertainment/article/Postcards-from-theedge-of-Emeryville-3228436.php. estimations for the project was a major challenge. Thus, having sufficient funding for the project helped the staff to address various problems. For example, it is difficult to completely measure and characterize the soil contaminates. Funding provides the flexibility to react to the new information when it becomes available. Furthermore, it is challenging to negotiate the cost of improvement through development and design with the private sector. ${ }^{66}$

The project revealed that it is beneficial to involve various organizations early on in the remediation process before the purchasing the property in order to avoid any unforeseen circumstances. Due to the large number of railroads within Emeryville, the City is very familiar with railroad redevelopments. For this reason, the City can serve as a regulatory agency for less complex projects.

64 Rails-To-Trails Conservancy, Understanding Environmental Contaminant: Lessons Learned and Guidance to Keep Your RailTrail Project on Track, (Washington D.C.: TRAILDART, 2004), 22, accessed April 11, 2014, http://www.railstotrails.org/resources/ documents/resource_docs/EPAReport.pdf.

65 bid., 23.

66 bid. 


\section{Partnership for Successful Project Olmsted Linear Park, Atlanta, Georgia}

\section{Background}

Olmsted Linear Park consists of six segments totaling 45 acres. The park's condition became progressively worse over the years. The linear park, instead of being a destination, became "a place to avoid." The Georgia Department of Transportation's plans for construction of a highway that might segregate the community and the park resulted in a lack of interest in the linear park. Consequently even those who were most engaged, such as members of the Druid Hills Garden Club which had been invested in the Oak Grove segment since the late 1920s, were discouraged. ${ }^{67}$

To stop the highway project and to improve the condition of the park, the Olmsted Parks Society of Atlanta was established in 1983. After a decade of aggressive opposition to the highway proposal, the court ruled against turning the parkland into a road. In 1995, the Olmsted Parks Society of Atlanta, Inc., Druid Hills Civic Association, Park Pride, Druid Hills Garden Club, City of Atlanta, DeKalb County and Fernbank, Inc., partnered together to develop a Master Plan for the Park. ${ }^{68}$

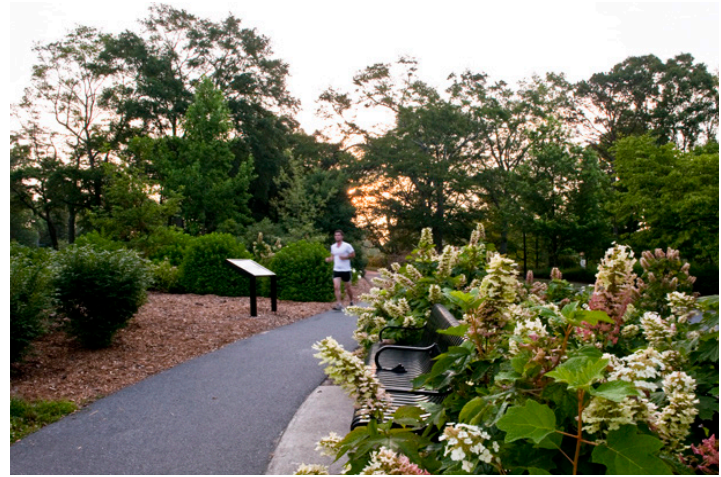

Figure 12 Olmsted Linear Park

Source: National Association for Olmsted Parks, accessed October 4, 2014, http://www.olmsted.org/olmst-

It took fourteen years to rehabilitate the linear park. The plan for restoration of the linear park included: restoring the initial layout, reestablishing the row of trees along Ponce de Leon Avenue, planting thousands of long-lived flora and fauna, trees, and shrubs, as shown in Figure 12, removing invasive plants, installing granite curbstones to prevent storm water from causing erosion, hiding the utility lines underground, installing street lights, building new pedestrian routes that meet ADA requirements, installing benches and interpretive signage, and constructing bridges. A playground was also included to the plan to serve as a destination for children. ${ }^{69}$

\section{Funding and other sources}

The Druid Hills Civic Association, Fernbank Inc, as well as local foundations such as the Robert W. Woodruff Foundation and the Arthur Blank Foundation, the City of Atlanta, DeKalb County, and the Georgia Department of Transportation partnered collaboratively to sponsor the project. Numerous citizens have also contributed with their generous donations. ${ }^{70}$

67 National Association for Olmsted Park, Olmsted Linear Park, accessed October 4, 2014, http://www.olmsted.org/olmstedlinearpark-atlanta-ga.

68 Ibid.

69 Ibid.

70 Ibid. 


\section{Findings}

The project mainly showed the importance of long-lasting impact of local community persistence. The collaboration of a wide range of stakeholders (such as community organizations, environmental, public health, and park advocates, other local non-profit entities, educational institutions, and local governments) exposed the consequences of constructing a new highway on the community, and the benefits of preserving historical and ecological value of the park. Only a partnership could finally lead to win the opposition against local and state government. ${ }^{71}$

In order to engage stakeholders, multiple educational tours of the park were organized to introduce visitors to the historical background and contemporary characteristics of the park, as well as its potential future. Interpretative signage helped visitors to recognize the science and art of the various species within the park. Moreover, alternative additions such as a playground were considered to maintain its reputation as a safe place, even for residents from beyond the neighborhood. The goal is to bring a diverse group of people to the park. ${ }^{72}$

The project also revealed that park maintenance is much less attractive than restoration through private donors and corporate sponsors. It is important to educate the community to recognize that restoration is only the beginning, and that maintenance will be a continuing challenge. Maintenance is costly and time-consuming, and stakeholders must come up with a maintenance plan as well as sources of funding. ${ }^{73}$

\section{Plan to Turn Threats into Opportunities City of Kalispell, Montana}

\section{Background}

The City of Kalispell has envisioned a plan to revitalize the Core Area while maintaining its characteristics and identity. One of the primary goals of the Core Area Plan, as shown in Figure 13, is to replace the railroad tracks with linear parks which will provide pedestrian oriented connection.

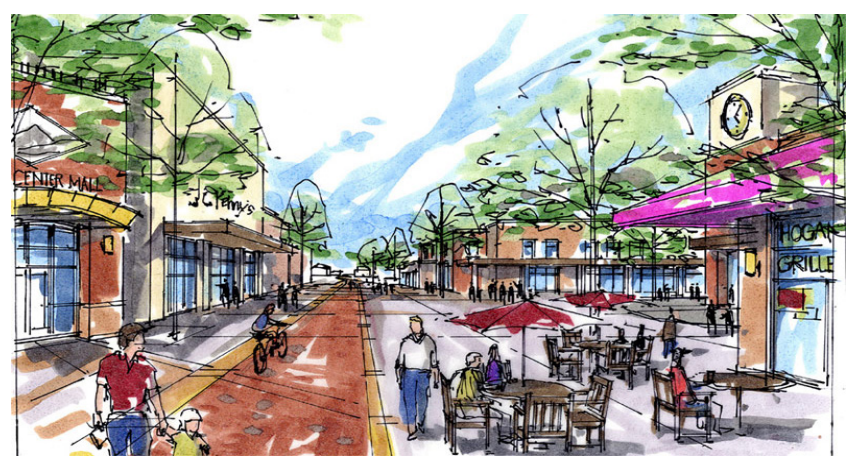

Figure 13 Possible Future Redevelopment in Kalispell Source: Render by CTA Architects Engineers, accessed October 12, 2014, http://flatheadbeacon.com/2012/09/05/whatsnext-for-kalispell/.

71 National Association for Olmsted Park, Olmsted Linear Park, accessed October 4, 2014, http://www.olmsted.org/olmstedlinearpark-atlanta-ga.

72 Ibid. 
After more than 20 years of public debate, the Kalispell Core Area planning is now moving forward with the active implementation phase. The implementation of the Linear Park plan relies on removing blight, maximizing private investment, and enhancing the community's amenities. ${ }^{74}$

\section{Funding and other sources}

Based on the availability of funding, the linear park would be implemented in different phases. The entire project, from removing the tracks all the way to completion, projected to take three years. The estimated cost in the beginning years would be $\$ 1.5$ million. However, a 10 -year timeframe to develop the linear park would cost approximately $\$ 4.45$ million. A combination of grant funding, incremental real property tax revenues and tax increment finance funds would cover the capital costs for the linear park project. ${ }^{75}$ Figure 14 shows the projects design concept for removing railroad trac and replacing it with a linear park.

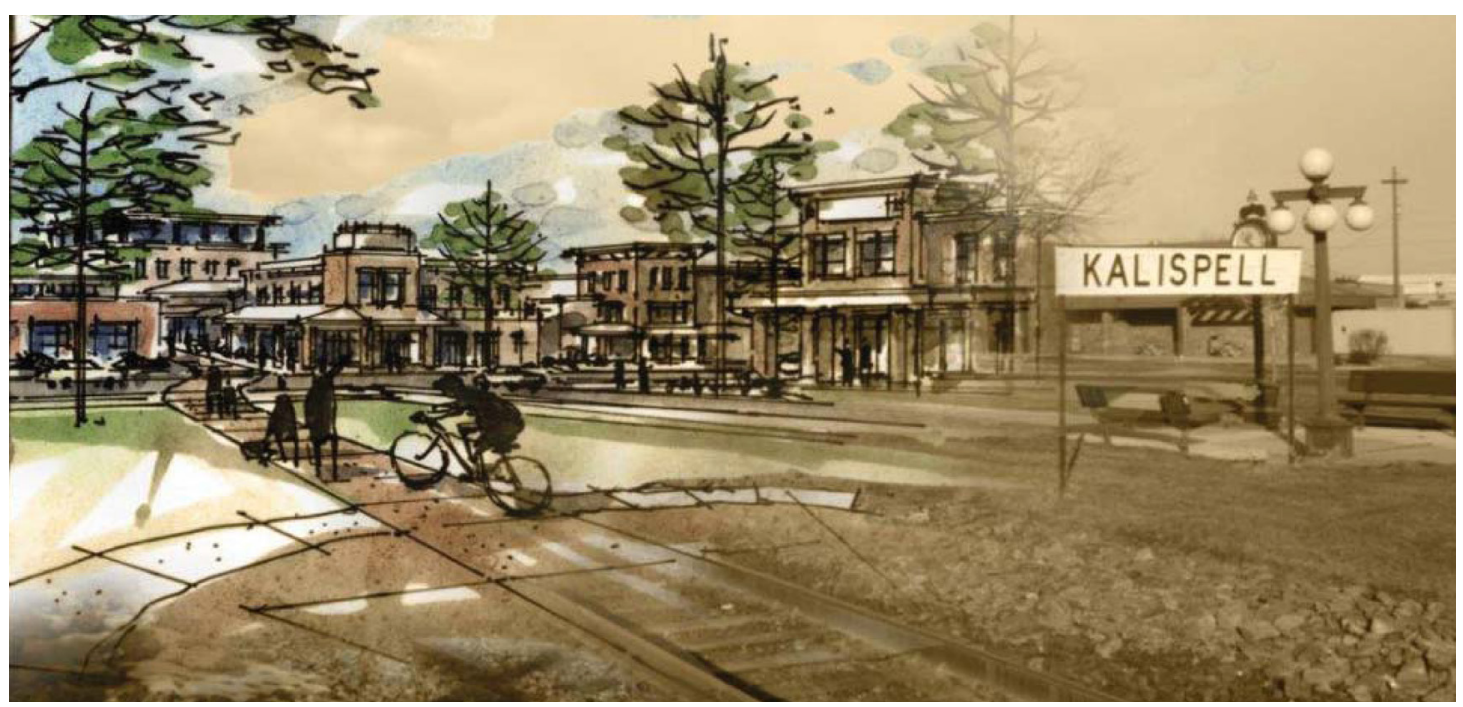

Figure 14 Linear Park Development and Green Space Replacing the Railroad Track

Source: Render by CTA Architects Engineers, accessed October 12, 2014, http://flatheadbeacon.com/2012/09/05/ whatsnext-for-kalispell/.

There are three major components for estimating the cost of the Kalispell Linear Park. The first is the removal of the rail freight line, the cost of which is subject to change. Second is installation of the Linear Park trail, which is expected to be a low impact construction project. This is because the city's existing power, water, wastewater, and road infrastructure are in good condition and have the capacity to serve the proposed linear park plan. The primary cost would be the street extensions and the installation of basic pedestrian-oriented infrastructure such as street lights, curb cuts, sidewalks, etc. Third, street connections and the construction of facilities and equipment for the linear park, which will be implemented based on availability of funding. ${ }^{76}$

74 City of Kalispell, Core Area Plan Market \& Feasibility Study, June 2013, 47, accessed September 22, 2014, http://flatheadbeacon. com/2013/06/30/kalispell-revitalization-plan-taking-shape/.

75 Ibid., 65.

76 Ibid, 49. 


\section{Findings}

The linear park would improve pedestrian and bike access, and consequently increase safety and mobility in the Core Area. It would also provide a location for a public gathering place. The Linear Park would also function as a center of activity for the neighborhood and encourage varied dining and entertainment uses. Currently, the Core Area lacks establishments that create a destination area for residents. The plan would also provide opportunity to grow for surrounding uses. $^{77}$

A summary of the high-level parameters in planning the linear park's layout is listed below:

- Attracting private investment in development

- Upgrading basic public infrastructure such as sidewalks and street lights

- Improving access through new street which previously was blocked

- Increasing safety by connecting pedestrians to recreational amenities

- Investing in new trail heads at key locations

The following provides an overview of the proposed layout for the Kalispell Linear Park:

- Connect the planned trail to the existing trails

- Construct an open air farmer's market and a focal gathering "third place"

- Provide a senior outdoor fitness park with outdoor exercise equipment

- Permitting portable vending carts

- Partnering with Flathead Electric Co-Op, an underutilized site to redevelop the site to a lowcost comfort station

77 City of Kalispell, Core Area Plan Market \& Feasibility Study, June 2013, 68, accessed September 22, 2014, http://flatheadbeacon. com/2013/06/30/kalispell-revitalization-plan-taking-shape/. 


\section{Chapter 5: Safety Concerns}

Public parks and open spaces play a major role in enhancing human life by reducing air and water pollution, preventing suburban sprawl, expanding recreational opportunities, supplying tree canopies, attracting businesses, and enhancing property values. ${ }^{78}$ Although linear parks are popular and successful, there are several concerns about the impact of the proposed linear park on communities before and during the construction phase. ${ }^{79}$ Opponents usually believe that linear parks attract drug dealers and other criminals. ${ }^{80}$ Vandalism, graffiti, and homeless encampments were the signs that make public and city authorities think that the linear parks will serve other purposes than a public gathering place. ${ }^{81}$

However, by cleaning up the landscape and attracting people for recreation and transportation uses, converting a rail corridor into an urban open space actually tends to reduce crime..$^{82}$ Advocates for open spaces must be prepared to respond to concerns by creating opportunities such as hosting activities or informal gatherings for trail users and neighborhood residents' engagement in developing solutions. ${ }^{83}$

Users are the most important stakeholder in terms of safety for urban greenways. Hence, greenway characteristics should be prioritizing based on their use. For residents, natural ecology preservation, recreation, as shown in Figure 15, and non-motorized transportation are the most preferred functionality of a greenway in an urban environment. Therefore, involvement of stakeholder is the first identified guideline. Physical design and maintenance of the linear parks are very crucial for urban open space safety. Lights, signs and maps, vegetation management, pathway options, policing, and activity generators are among the recommended criteria for designing and managing linear parks and open spaces. $^{84}$

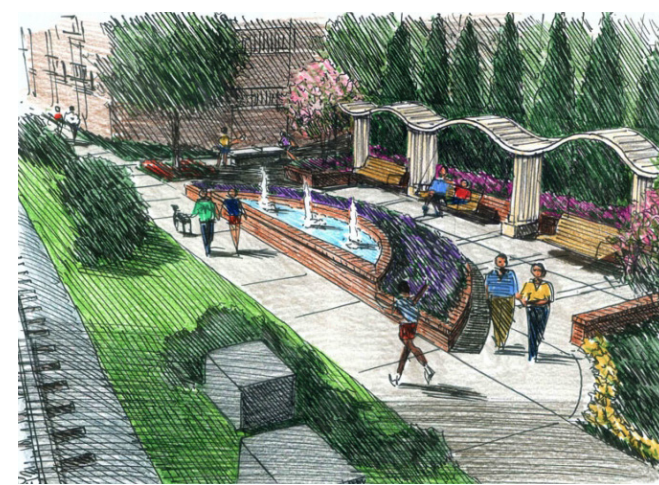

Figure 15 Linear Park with Recreational Use Source: Rail Trail Vision: Episode Renderings, accessed October 12, 2014, http://www.

charlottecentercity.org/business/initiatives-2/railtrail-vision/rail-trail-vision-episode-renderings/

78 City of Durahm, Crime Prevention through Environmental Design: Durham Guide to Creating a Safer Community, accessed April 7, 2014, http://www3.cutr.usf.edu/security/documents\%5CCPTED\%5CRaleigh.pdf

79 Rails-to-Trails Conservancy, Urban Pathways to Healthy Neighborhoods: Personal Safety, accessed September 20, 2014, http://www.railstotrails.org/resources/documents/ourWork/PromotingTrailUse/UPI/Urban\%20Pathways\%20to\%20Healthy\%20 Neighborhoods_Safety_letter.pdf.

80 Rails-to-Trails Conservancy, Rail-Trails and Safe Communities: The Experience On 372 Trails, January 1998, 1, accessed September 10, 2014, http://www.railstotrails.org/resources/documents/resource_docs/Safe\%20Communities_F_lr.pdf 81 Ibid., 2.

82 Ibid., 1.

83 Rails-to-Trails Conservancy, Urban Pathways to Healthy Neighborhoods: Personal Safety, accessed September 20, 2014, http:// www.railstotrails.org/resources/documents/ourWork/PromotingTrailUse/UPI/Urban\%20Pathways\%20to\%20Healthy\%20 Neighborhoods_Safety_letter.pdf.

84 Don T. Luymes, and Ken Tamminga, "Integrating Public Safety and Use into Planning Urban Greenways," Landscape and Urban Planning 33 (1995): 397. 


\section{Design Guidelines}

Urban design can significantly affect communities. By implementing urban design guidelines, open spaces can experience a variety of activities to satisfy the needs of the community, people can feel a sense of ownership and belonging, and places can support healthy lifestyles by promoting walkability. The design principles of crime prevention can be used to create places that are safe and secure for all users, and people like to be in and return to. In urban design it is also important to address distinctive local qualities of places such as cultural history, topography, natural landscape, or community diversity to make the place special and memorable. ${ }^{85}$

\section{Crime Prevention Through Environmental Design}

Crime prevention through environmental design (CPTED) uses design guidelines to decrease criminal behavior, to encourage people to self-police, and to "keep an eye out" for each other; in order to create safe, and livable communities. ${ }^{86} \mathrm{CPTED}$ has come up with a range of design guidelines in the built environment such as natural surveillance, access control, and territoriality to address potential crime and safety issues. ${ }^{87}$

\section{Natural Surveillance}

There are different measures in the built environment that can address natural surveillance and clear sight lines. Orientation of buildings in such a way that windows or porches face the trail provides a clear view of the trail creats an effect known as "eyes on the trail". 88

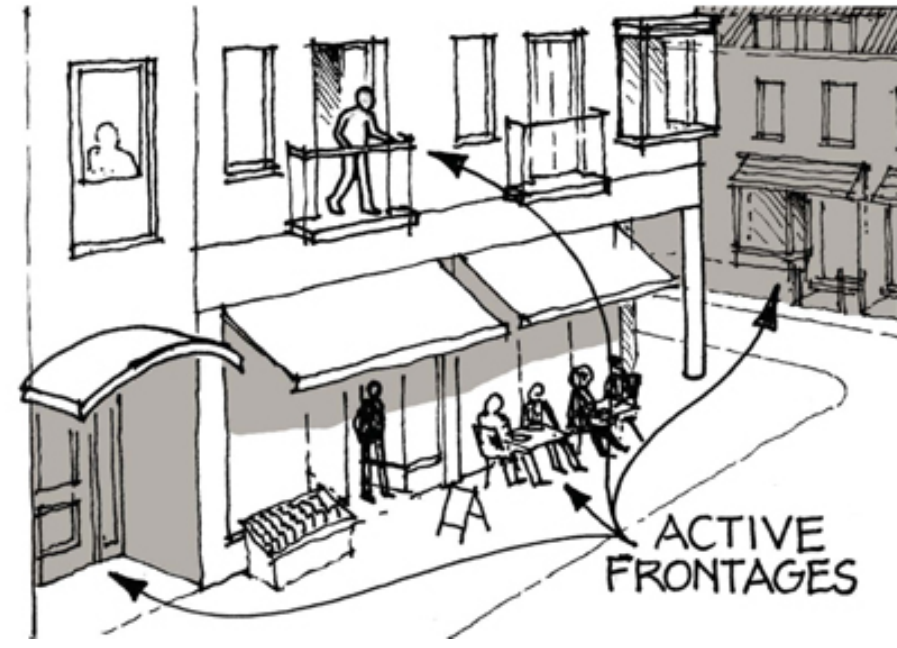

Figure 16 Active Frontage

Source: Building Futures, accessed October, 12, 2014, http://www. hertslink.org/buildingfutures/designs/16952825/16952830/.

85 Moreton Bay Regional Council, “Urban Design Charter," accessed October 2, 2014, https://www.moretonbay.qld.gov.au/ uploadedFiles/moretonbay/development/planning/Urban-Design-Charter.pdf. 86 City of Durahm, Crime Prevention through Environmental Design: Durham Guide to Creating a Safer Community, accessed April 7, 2014, http://www3.cutr.usf.edu/security/documents\%5CCPTED\%5CRaleigh.pdf.

87 St. Petersburg Police Department, What is CPTED?, accessed September 5, 2014, http://www.stpete.org/police/pdf/crime-prev/ CPTEDbrochure. pdf.

88 Rails-to-Trails Conservancy, Urban Pathways to Healthy Neighborhoods: Personal Safety, accessed September 20, 2014, http:// www.railstotrails.org/resources/documents/ourWork/PromotingTrailUse/UPI/Urban\%20Pathways\%20to\%20Healthy\%20 
Surveillance is the most important factor to ensure safety in parks and public places. The type of planting, density of trees, type of lighting, clear entrances, and visibility from buildings' front porches or windows and active frontages, as shown in Figure 16 in the previous page, are among design guidelines that can provide safety for users. Trimming overgrown vegetation and tall shrubs minimizes hiding places along the trail and provides better sight lines for users. ${ }^{89}$ Table 4 summarizes specific natural surveillance design guidlines.

Table 4 CPTED Natural Surveillance Design Guidlines

\begin{tabular}{|l|l|}
\hline \multirow{5}{*}{ Natural } & \multicolumn{1}{c|}{ Guidelines } \\
\cline { 2 - 2 } & Planting that maintains visibility and minimize opportunities for intruders to hide \\
\cline { 2 - 2 } & Usage of ground shrubs less than three feet in height, and trimming trees to a height of 10 feet \\
\cline { 2 - 3 } & Good sightlines, clear entrances, exits, and pathways \\
\cline { 2 - 3 } & Lighting should not produce shadows close to pathways and entries or exits \\
\cline { 2 - 3 } & Appropriate nighttime lighting \\
\cline { 2 - 3 } & Front porches \\
\cline { 2 - 3 } & Pedestrian-friendly sidewalks and streets \\
\cline { 2 - 3 } & Unobstructed doors and windows \\
\hline & Buildings should face the public spaces, parks and play grounds \\
\cline { 2 - 3 } & Visibility of people, parking areas, and building entrances \\
\cline { 2 - 3 } & Building gates that is easily visible from the streets \\
\cline { 2 - 3 } & Active frontage (such as restaurants, businesses and shops which open at night and after hours) \\
\hline & Visibility from surrounding buildings and land uses \\
\cline { 2 - 3 } & Building orientation that supports natural surveillance of adjacent open space \\
\hline & Avoid dense vegetation and shrubs along walking paths \\
\hline
\end{tabular}

Source: National Crime Prevention Council, “Crime Prevention through Environmental Design," (Singapore, Public Affairs Department, 2003), 4, accessed September, 5, 2014, http://www.ncpc.gov.sg/images/media/CPTED.pdf.

\section{Access}

Access related design elements aims to eliminate criminal accessibility. This design feature increases access and visibility to the public realm and decreases access to private spaces. For example a highly visible gate, as it shown in Figure 17, door and window locks, fencing, signage controls access between public and private spaces. ${ }^{90}$ Table 4 summarizes specific access design guidlines.

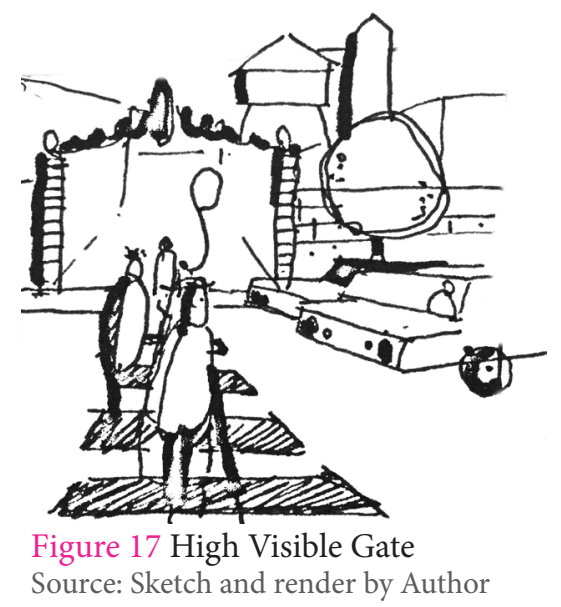

89 National Crime Prevention Council, "Crime Prevention through Environmental Design," (Singapore, Public Affairs Department, 2003), 4, accessed September, 5, 2014, http://www.ncpc.gov.sg/images/media/CPTED.pdf. 90 City of Portland, Office of Neighborhood Involvement, Crime Prevention through Environmental Design, Spring 2009, 1, accessed October 12, 2014, http://www.portlandoregon.gov/oni/article/320548. 
Table 5 CPTED Access Design Guidlines

\begin{tabular}{|l|l|}
\hline \multirow{4}{*}{ Access } & \multicolumn{1}{c|}{ Guidelines } \\
\cline { 2 - 3 } & Design elements to indicate public routes and discourage access to private areas and structuralelements \\
\cline { 2 - 3 } & $\begin{array}{l}\text { People can be guided through a space by the strategic design of streets, sidewalks, building entrances, } \\
\text { landscaping, and neighborhood gateways }\end{array}$ \\
\cline { 2 - 3 } & Blocking access to crime targets and creating a perception of risk for offenders \\
\cline { 2 - 3 } & Multiple entrances and exits \\
\cline { 2 - 3 } & Continuous walking path and biking route \\
\cline { 2 - 3 } & Access to public transportation \\
\hline
\end{tabular}

Source: National Crime Prevention Council, “Crime Prevention through Environmental Design," (Singapore, Public Affairs Department, 2003), 4, accessed September, 5, 2014, http://www.ncpc.gov.sg/images/media/CPTED.pdf.

\section{Maintenance}

Keeping the trail well maintained contributes to the linear park attractiveness. Maintaining the cleanliness of the linear park corridors reinforces a sense of ownership, will increase linear park use, and reduce the occurrence of litter, graffiti, and vandalism. ${ }^{91}$ Well-kept landscapes increase the sense of safety. However, the density of the trees has a different impact on the sense of safety based on the neighborhoods wealth. In wealthy neighborhoods, high-density trees that block the view, usually decrease the sense of safety. However, in underserved neighborhoods, trees represent a nicer neighborhood and "civilized character" and increases the sense of safety. Residents' volunteer contribution in greening and maintaining can help eliminating chief costs of such activities. ${ }^{92}$ Therefore, in order to keep the parks safe, resilient management and maintenance will be crucial. Table 5 summarizes specific maintenance design guidlines.

Table 6 CPTED Maintenance Design Guidelines

\begin{tabular}{|l|l|}
\hline \multirow{4}{*}{ Maintenance } & \multicolumn{1}{c|}{ Guidelines } \\
\cline { 2 - 2 } & Proper maintenance of plant and lighting \\
\cline { 2 - 3 } & Prevent over/under trimming shrubs \\
\cline { 2 - 2 } & Maintenance clear sightlines \\
\cline { 2 - 2 } & Bypass fragile landscapes \\
\cline { 2 - 2 } & Engage residents and promoting sense of ownership \\
\cline { 2 - 2 } & Avoid blank walls and fences \\
\hline
\end{tabular}

Source: National Crime Prevention Council, "Crime Prevention through Environmental Design,” (Singapore, Public Affairs Department, 2003), 4, accessed September, 5, 2014, http://www.ncpc.gov.sg/images/media/CPTED.pdf.

91 Rails-to-Trails Conservancy, Urban Pathways to Healthy Neighborhoods, accessed September 5, 2014, http://www.railstotrails. org/ourWork/promotingTrailUse/urbanpathways/issue-summaries/safety.html. 


\section{Landscaping, Lighting, and Signage}

Signage, art, or landscaping establishes a sense of ownership, conveys the unique identity of the neighborhood, ${ }^{93}$ demonstrates that the trail is cared for, and creates an environment where "crime is uncomfortable. ${ }^{94 "}$ The type and design of the pavement should be chosen in order to improve drainage, eliminate puddles, and reduce dust. Murals help in beautification and improving community bounds. Lighting is a very important component to provide safety by improving visibility and discouraging litter, graffiti, and criminal activity. Emergency vehicle access should be provided for the time of disaster. Emergency phones or call boxes, as shown in Figure 18, should be placed strategically, and the linear parks' addresses should be mapped to the cities database for police dispatch to locate crimes. ${ }^{95}$ Table 6 summarizes specific Landscaping design guidlines.

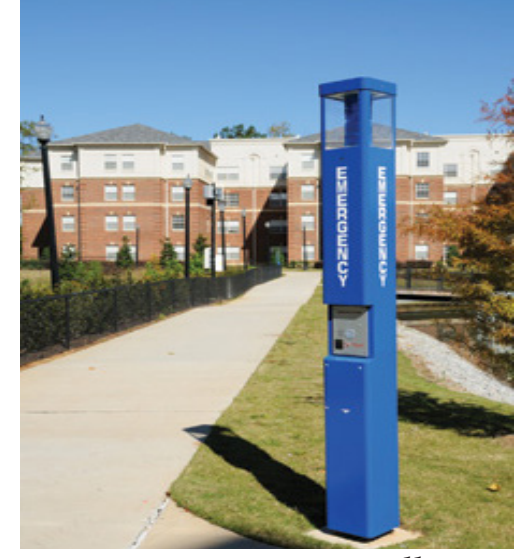

Figure 18 Emergency Call Box Source: Stanley Security, accessed November, 3 , http://www. stanleysecuritysolutions.com/markets/ k-12-education/products.

Table 7 CPTED Landscaping Design Guidelines

\begin{tabular}{|l|l|}
\hline \multirow{4}{*}{\begin{tabular}{c} 
Landscaping, \\
Lighting and \\
\cline { 2 - 2 } \begin{tabular}{c} 
Signage \\
\cline { 2 - 2 }
\end{tabular}
\end{tabular}} & Legitimate activity by users of public spaces after dark \\
\cline { 2 - 2 } & Appropriate types of lighting fixtures \\
\cline { 2 - 3 } & Using signage to indicate safe places and routes \\
\hline
\end{tabular}

Source: National Crime Prevention Council, "Crime Prevention through Environmental Design," (Singapore, Public Affairs Department, 2003), 4, accessed September, 5, 2014, http://www.ncpc.gov.sg/images/ media/CPTED.pdf.

\section{Park Patrols}

Linear park developers have an option to install neighborhood safety watch cameras or "neighborhood watch" signs, as shown in Frigure 19. In addition, patrols are also very useful for addressing residents' and linear park users' concerns and minimize the potential for crime.

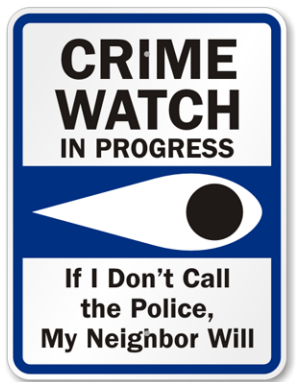

Figure 19 Neighborhood Watch Sign

Source: accessed October 12, 2014, http://www.mysecuritysign.com/blog/wpcontent/uploads/2013/05/N

93 City of San José, Strong Neighborhood Initiative, Spartan Keyes: Neighborhood Improvement Plan Amendment, (San José, CA: City of San José, 2008), 51, accessed February 11, 2014, http://www.publicvisionresearch.com/community/Spartan_Keyes.pdf. 94 Rails-to-Trails Conservancy, Urban Pathways to Healthy Neighborhoods, accessed September 5, 2014, http://www.railstotrails. org/ourWork/promotingTrailUse/urbanpathways/issue-summaries/safety.html.

95 Prince William County Police Department, CPTED Strategies: A guide to safe environments in Prince William County, Virginia., 23, http://www.pwcgov.org/government/dept/police/documents/002035.pdf. 
Working with police, and creating volunteer or professional patrols can also accommodate the safety needs of linear parks. Patrols can consist of people who do informal monthly clean-ups and educate residents about the park and emergency assistance. A regular presence of a police or a volunteer patrol will help in reducing fear and the perception of crime and violence. ${ }^{96}$

\section{Responsive Environment}

A responsive environment is a place that has been built based on "democratic setting" to address social ideals. This type of environment provides opportunities for its users to choose from different options that are available for them in urban settings. ${ }^{97}$ The seven design elements for responsive design, as shown in Figure 20, are permeability,variety, legibility, robustness, visual appropriateness, personalization. ${ }^{98}$ Creating a responsive environment through urban design elements in open spaces shift participations from being passive to active, and fear zones become urban destinations. Interactive public open spaces create spatial democracy, improve transparency, and enhance the image of the city as a secure environment. ${ }^{99}$

\section{Permeability}

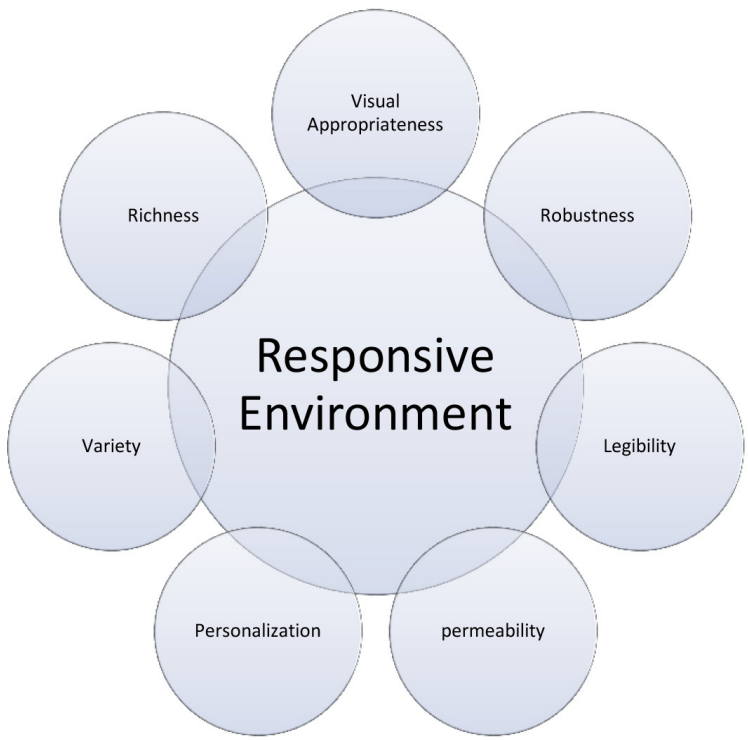

Figure 20 Responsive Environment Diagram

Source: Sue McGlynn et al., Responsive Environments: A Manual for Designers, ed. Ian Bentley, trans. Mostafa Behzadfar, (Tehra, Iran: Iran University of Science \& Technology Publication, 2003).

Permeability, also defined as accessibility, plays a major role in making an urban environment responsive. Providing multiple route options make a place accessible and, correspondingly, permeable. ${ }^{100}$ The main design features that have considerable effect on permeability consist of: shape and size of blocks, hierarchy of roads, pedestrian and auto mobile segregation, and delineated public and private spaces. ${ }^{101}$

96 Rails-to-Trails Conservancy, Rail-Trails and Safe Communities: The Experience On 372 Trails, January 1998, 3, accessed September 10, 2014, http://www.railstotrails.org/resources/documents/resource_docs/Safe\%20Communities_F_lr.pdf. 97 Omar M. El Hosseiny, "Permeability: A Key Measure For Responsiveness In Urban Design (Case Study Of Cairo C.B.D.)," First International conference on quality of like in cities, Singapore (March 1998): 1, accessed October 1, 2014, http://www.cpas.com/pdf/Omar\%20El\%20Hosseiny/009.pdf.

98 Sue McGlynn et al., Responsive Environments: A Manual for Designers, ed. Ian Bentley, trans. Mostafa Behzadfar, (Tehran, Iran: Iran University of Science \& Technology Publication, 2003), 15-33.

99 United Nations Interregional Crime and Justice, Improving Urban Security through Green Environmental Design, accessed November 30, 2014, http://www.unicri.it/news/files/2011-04-01_110414_CRA_Urban_Security_sm.pdf.

100 Omar M. El Hosseiny, 1.

101 Ibid., 10 . 
Small blocks often provide an increase in choice and awareness to users by providing viewshed from one point to another. Small blocks also encourage walking and increase pedestrian safety. ${ }^{102}$

Figure 21 ilustrates that in its current condition the largeblock only offers two access points (One and two) and one rout. However, if only access number three would be created,the layout would change into small blocks and three access points and three alternative routs would be created. In addition, the new alternative routes have a slightly shorter length than the existing route.

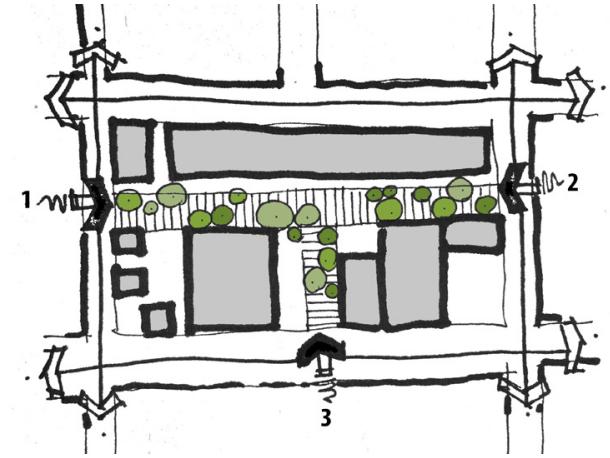

Figure 21 Current and Recommended Access Points to 4 th Street Line

Source: Sketch and render by Author

Visual permeability or visibility of those alternatives is also crucial because, otherwise, people, other than residents of the neighborhood that are familiar with the area, cannot benefit from them. Therefore, shape of blocks also matters. Blocks that are simple and have orthogonal shapes are easier to be noticed from one junction to another. ${ }^{103}$ Increasing the level of activity around their entrances can also enhance physical permeability in public spaces. ${ }^{104}$ Figure 22 shows the future location of the Neighborhood Action Center on erd street's recomended access point.

\section{Variety}

The type and location of activities and uses within the site define level of experimental choice that the place offers. An environment with variety has a diverse set of buildings, and attracts different types of people at different times for different sets of activities. However, variety cannot only be achieved by dumping random sets of activities in a place. The various uses of a place must mutually support one another.

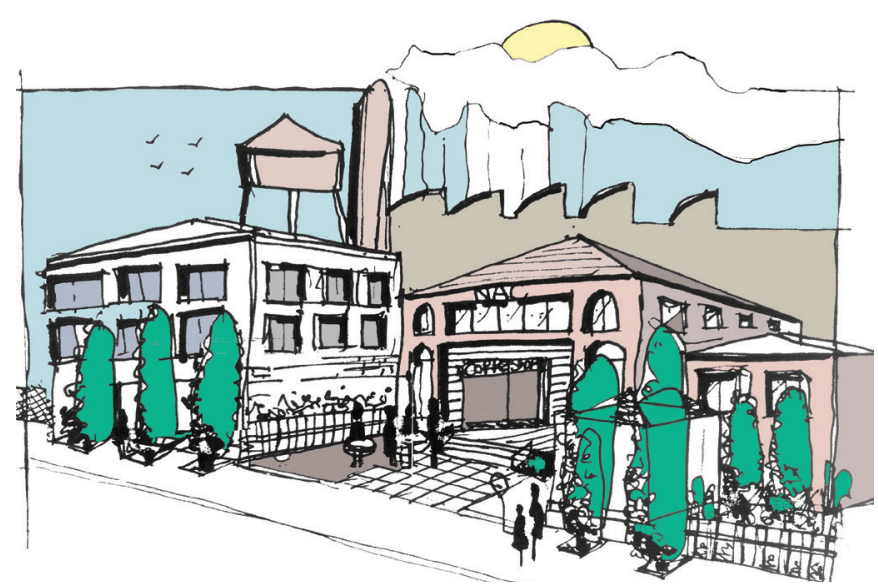
A layout that includes primary uses, such as Figure 22 Neighborhood Action Center, View from 3rd Street grocery stores, that help support secondary Source: Sketch and render by Author uses, such as special shops, restaurants, and boutiques, promotes variety. ${ }^{105}$

102 Sue McGlynn et al., Responsive Environments: A Manual for Designers, ed. Ian Bentley, trans. Mostafa Behzadfar, (Tehran, Iran: Iran University of Science \& Technology Publication, 2003), 15-33.

103 Omar M. El Hosseiny, "Permeability: A Key Measure For Responsiveness In Urban Design (Case Study Of Cairo C.B.D.)," First International conference on quality of like in cities, Singapore (March 1998): 3, accessed October 1, 2014, http://www.cpas.com/pdf/Omar\%20El\%20Hosseiny/009.pdf 104 Ibid., 8.

105 Sue McGlynn et al., Responsive Environments: A Manual for Designers, ed. Ian Bentley, trans. Mostafa Behzadfar, (Tehran, Iran: Iran University of Science \& Technology Publication, 2003), 59-70. 


\section{Legibility}

Legibility could be defined as activity patterns and physical forms of the environment. Legibility means how easily users can grasp a place and understand where the location of different uses are. In today's modern cities, large office developments are visually overwhelming places and cause confusion in activity patterns. In such environments, people are left wondering through endless streets among buildings that look identical.

Kevin Lynch broke down the urban settings into five key physical elements. These five elements are listed below, can be used to create a legible environment. ${ }^{106}$

- Paths: channels of movement such as streets, alleyways, roadways, and railways

- Nodes: focal points and junctions of paths

- Landmarks: reference points for users located at junctions that are visible from a distance

- Edges: linear elements such as buildings, rivers, railways, and motorways that act as barriers and invisible thresholds to variety of places

- Districts: medium to large sections of a city that have a particular identifying character

Places that are legible can be easily understood and comprehended. Individuals can easily understand the well organized and distinct hierarchy of street layouts, and connect and navigate through these places. ${ }^{107}$ In such designs, the street network not only is the movement structure, but also the fundamental layout for the urban pattern. Landmark features are important for navigation and providing a foundation for an accessible built environment. ${ }^{108}$

\section{Robustness}

A place that can be used for different activities has the quality of robustness. The flexibility and robustness of a place is identified by its ability to adapt to changes over time. ${ }^{109}$ A robust environment, as shown in Figure 23, focuses on the users' interest rather than the penetrants. In public places, activities offer support for each other. Activities surrounding buildings strongly influence the public space. Edges should have as many entrances as possible with many access points to promote visibility and permeability. Uses of places should not inhibit one another. ${ }^{110}$

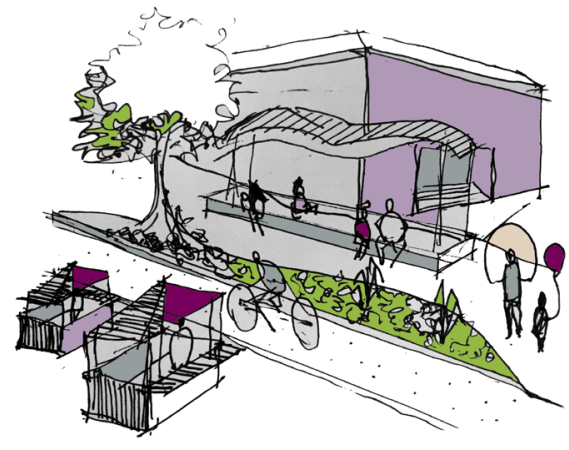

Figure 23 Flexible Open Space Source: Sketch and render by Author

106 Ibid., 113-126.

107 Moreton Bay Regional Council, “Urban Design Charter,"14, accessed October 2, 2014,

https://www.moretonbay.qld.gov.au/uploadedFiles/moretonbay/development/planning/Urban-Design-Charter.pdf.

108 Ibid., 12.

109 Ibid.

110 Sue McGlynn et al., Responsive Environments: A Manual for Designers, ed. Ian Bentley, trans. Mostafa Behzadfar, (Tehran,

Iran: Iran University of Science \& Technology Publication, 2003), 157-66. 


\section{Visual appropriateness}

Visual appropriateness brings meaning to the site by incorporation of visual cues that enhance the character of the space. The meaning that users interpret from the use of a place allows them to adopt exploratory attitude towards it that place considered visually appropriate, different users have a different interpretation of a place, environmental experiences, and objective towards the place make those interpretations. ${ }^{111}$

\section{Personalization}

In public spaces, personalization is the ability for users to have their own stamps on the spaces. Numerous artist lofts are located in Spartan Keyes. ${ }^{112}$ These artists are assets for the community and their arts can be displayed in the open space.

\section{Richness}

Places that engage all the senses in order to navigate and understand the built environment are more enjoyable to be in. ${ }^{113}$ Vision is the dominant sense for many people. Visual contrasts such as light, shade, as shown in Figure 24,, color, and building material can increase visual richness. Viewing distance and viewing time also effect visual richness. Non-visional senses such as, sense of smell, motion, touch, and hearing are all involved in creating spaces with quality of richness. ${ }^{114}$

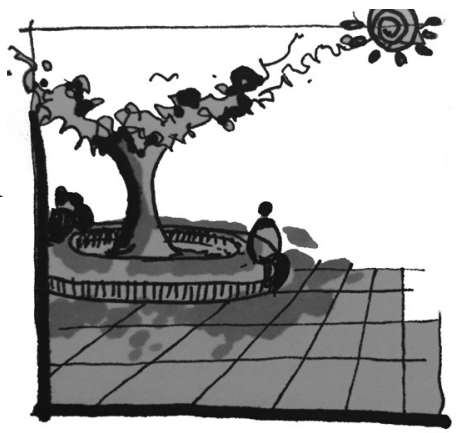

Figure 24 Light and Shade

Source: Sketch and render by Author

111 Ibid, 227.

112 Neighborhood Assessment and Community Engagement: Spartan Keyes (San José, CA: Urban Planning at San José State University, 2013), 56, accessed April 5, 2014, http://www.sjsu.edu/urbanplanning/docs/SpartanKeyesCommunityAssessmenpdf. 113 Moreton Bay Regional Council, "Urban Design Charter,"14, accessed October 2, 2014, https://www.moretonbay.qld.gov.au/uploadedFiles/moretonbay/development/planning/Urban-Design-Charter.pdf. 


\section{Chapter 6: Conclusion and Recommendations}

Considering the efficiency of open space corridors within urbanized areas, and benefits of reusing abandoned lands for creating parks and green spaces, this project analyzed the feasibility of converting the abandoned brownfield site in the Spartan Keyes neighborhood into an open space and provided recommendations and guidelines to achieve that goal. Considering pollution and safety as two major reasons preventing this particular parcel from being redeveloped, each concern has been studied in detail and methods are presented to overcome those constraints.

It is very important to pay attention to the neighborhood characteristics and residents' interests. This will help to create a vibrant environment that will provides safety, economic growth, and community needs for a neighborhood destination. The future open space in this parcel can include some local commercial uses such as community center, coffee shop, and restaurant. Neighborhood leaders have specifically mentioned their interest to have affordable activities and they want the linear park to be designed in a way to be open to food trucks and mobile vendors.

With the current trend in the neighborhood, multi-family housing developments are predicted to be built, and surrounding buildings will be converted into a residential use. Although this block is currently zoned as heavy industrial, the zoning can be changed into a residential mixed use. More residential development in the neighborhood means more people will move in Spartan Keyes and building a park is not a choice anymore. More residential redevelopment also means more revenue for the park trust fund, and Spartan Keyes must use this available funding to build a park in one of the potential sites.

4th Street Line may not be the ideal site for building a park for Spartan Keyes residents, but definitely has a high potential to be a neighborhood destination. Moreover, based on community leaders inputs this parcel has the highest priority for being developed as a linear park for neighborhood.

Different case studies showed that converting a brownfield into an open space is doable, but can be challenging. In order to overcome these challenges, the community needs a strong partnership for this specific goal. Unlike many of the abandoned railroad tracks that were turned into public open spaces, because people started walking and biking on them, the 4th Street Line is protected by fences, and no one currently uses this parcel for such activities.

City officials, for several reasons, expressed that they are reluctant to convert this parcel into a linear park. However, building a public open space in this parcel does not require the city to buy this piece of land and build a park on it. Therefore, by gathering the support and participation of residents, city authorities will consider policy implementation to streamline the linear park redevelopment process. 


\section{Bibliography}

Adams, David, Alan Disberry, Norman Hutchison, and Thomas Munjoma. "Mind the Gap! Taxes, Subsidies and the wwBe havior of Brownfield Owners." Land Use Policy 17 (2000): 135-145.

Alker, Sandra, Victoria Joy, Peter Roberts and Nathan Smith. “The definition of brownfield," Journal of Environmental Planning and Management 40, no.1 (2000): 49-69.

Belmont, Joseph. "Abandoned Rails of San José." Accessed May 12, 2013. http://www.abandonedrails.com/San_Jose_ California.

Bowen, Dawn S. "Building a Trail and Connecting a Community: The Establishment of the Dahlgren Railroad Heritage Trail.” Southeastern Geographer 49. no.3 (2009): 291-307.

Carnegie Mellon University. “Western Pennsylvania BROWNFIELDCENTER.” Accessed February 22, 2014. http:// www.cmu.edu/steinbrenner/brownfields/About/index.html.

Center for Creative Land Recycling (CCLR). "California's Brownfield Regulatory Agencies: Are all Cleanups Created Equal?” San Francisco: CCLR, 2006.

Chen, Ye, Keith W. Hipel, D. Marc Kilgour, and Yuming Zhu. "A Strategic Classification Support System for 'Brownfield Redevelopment.” Environmental Modeling and Software 24 (2009): 647-654.

City of Durham, Crime Prevention through Environmental Design: Durham Guide to Creating a Safer Community. Accessed April 7, 2014, http://www3.cutr.usf.edu/security/documents\%5CCPTED\%5CRaleigh.pdf.

City of Kalispell. Core Area Plan Market \& Feasibility Study. June 2013. Accessed September 22, 2014. http://flathead beacon.com/2013/06/30/kalispell-revitalization-plan-taking-shape/.

City of Portland. Office of Neighborhood Involvement. Crime Prevention through Environmental Design. Spring. Spring 2009. Accessed October 12, 2014. http://www.portlandoregon.gov/oni/article/320548.

City of San José. Memorandum. Spartan Keyes SNI Neighborhood Improvement Plan Amendment. Accessed May 7 , 2014. http://planning.sanjoseca.gov//planning/hearings/PC/2008/REPORTS/11-05/8b_SNI_SK.pdf.

City of San José. Envision San José 2040 General Plan. August 2007. Accessed February 20, 2014.

http://www.sanjoseca.gov/DocumentCenter/Home/View/474.

City of San José. Strong Neighborhood Initiative, Spartan Keyes: Neighborhood Improvement Plan Amendment. San José, CA: City of San José, 2008. Accessed February 11, 2014. http://www.publicvisionresearch. com/community/Spartan_Keyes.pdf.

Crewe, Katherine. "Linear Parks and Urban Neighborhoods: A Study of the Crime Impact of the Boston South-west Corridor." Journal of Urban Design 6. no. 3 (2001): 245-264.

Deason, Jonathan P., George William Sherk, and Gary A. Carroll, Public Policies and Private Decisions Affecting the Redevelopment of Brownfields: An Analysis of Critical Factors, Relative Weights and Areal Differentials. Accessed June 20, 2014. http://www.gwu.edu/ eem/Brownfields/project_report/chapters-html. htm. 
Deller, Thomas E., Bill Floriano, and Kristi Rea. "Vacant Lots." Accessed March 12, 2013. http://www.brown.edu/ Research/EnvStudies_Theses/summit/Briefing_Papers/Vacant_Lots/index.html.

De Sousa, Christopher. "Policy Performance and Brownfield Redevelopment in Milwaukee, Wisconsin." The Professional Geographer 57, no. 2 (2005): 312-327.

De Sousa, Christopher. "Urban Brownfields Redevelopment in Canada: The Role of Local Government." The Canadian Geographer / Le G'eographe canadien 50, no. 3 (2006): 392-407.

El Hosseiny, Omar M. "Permeability: A Key Measure For Responsiveness In Urban Design ( CASE STUDY OF CAIROC.B.D.).” First International conference on quality of like in cities, Singapore (March 1998): 1-10. Accessed October 1, 2014. http://www.cpas-egypt.com/pdf/Omar\%20El\%20Hosseiny/009.pdf

Environmental Law Institute. Brownfields Center. Accessed February 25, 2014. http://www.brownfieldscenter.org/ big/bfbasics.shtml.

Franzius, V. "Perspectives on the Remediation of Contaminated Land in Germany," Chemistry \&Industry 3 (2013): 505-508, Quoted in Christie R. M. Teeuw, Varied Policy of European Union States on Contaminated Lands. Hertfordshire, United Kingdom: University of Hertfordshire, 1998.

Hula, Richard C., and Rebecca Bromley-Trujillo. “Cleaning Up the Mess: Redevelopment of Urban Brownfields.” Economic Development Quarterly 24 (2010): 276-287.

Hutchinson, T. C., and K. M. Meema, ed. Lead, Mercury, Cadmium and Arsenic in the Environment. Chichester, New York, Brisbane, Toronto: John Wiley \& Sons, 1987.

Kuo, Frances E., Magdalena Bacaicoa, and William C. Sullivan. “Transforming Inner-City Landscapes: Trees, Sense of Safety, and Preference." Environment and Behavior 30 (1998): 28-59.

Luymes, Don T., and Ken Tamminga. "Integrating Public Safety and Use into Planning Urban Greenways.” Landscape and Urban Planning 33 (1995): 391-400.

McGlynn, Sue, Graham Smith, Alan Alcock, and Paul Murrain. Responsive Environments: A Manual for Designers. Edited by Ian Bentley. Translated to Persian by Mostafa Behzadfar. Tehran, Iran: Iran University of Science \& Technology Publication, 2003.

Moreton Bay Regional Council. “Urban Design Charter." Accessed October 2, 2014. https://www.moretonbay.qld.gov. au/uploadedFiles/moretonbay/development/planning/Urban-Design-Charter.pdf.

National Crime Prevention Council. “Crime Prevention through Environmental Design." Singapore, Public Affairs Department. 2003. Accessed September 5, 2014. http://www.ncpc.gov.sg/images/media/CPTED.pdf.

Neighborhood Assessment and Community Engagement: Spartan Keyes. San José, CA: Urban Planning at San José State University. 2013. Accessed April 5, 2014. http://www.sjsu.edu/urbanplanning/docs/ SpartanKeyesCommunityAssessment.pdf.

Nijkamp, Peter, Caroline A. Rodenburg, and Alfred J. Wagtendonk, "Success Factors for Sustainable Urban Brownfield Development: A Comparative Case Study Approach to Polluted Sites.” Ecological Economics 40 (2002): 235-252. 
Page, G. William, and R. S. Berger. "Characteristics and Land Use of Contaminated Brownfield Properties in Voluntary Cleanup Agreement Program." Land Use Policy 23 (2006): 551-559.

Page G. William, and R. S. Berger. "Property Characteristics of Contaminated Land in Environmental Cleanup Programs in New York State." Public Works Management Policy 10 (2005): 157-169.

Prince William County Police Department. CPTED Strategies: A guide to safe environments in Prince William County, Virginia. http://www.pwcgov.org/government/dept/police/documents/002035.pdf.

Rails-to-Trails Conservancy. Rail-Trails and Safe Communities: The Experience. On 372 Trails. January 1998. Accessed September 10, 2014. http://www.railstotrails.org/resources/documents/resource_docs/

Safe\%20Communities_F_lr.pdf.

Rails-To-Trails Conservancy. Understanding Environmental Contaminant: Lessons Learned and Guidance to Keep Your Rail- Trail Project on Track. Washington D.C.: TRAILDART, 2004. Accessed April 11, 2014. http://www. railstotrails.org/resources/documents/resource_docs/EPAReport.pdf.

Rails-to-Trails Conservancy. Urban Pathways to Healthy Neighborhoods: Personal Safety. Accessed September 20, 2014. http://www.railstotrails.org/resources/documents/ourWork/PromotingTrailUse/UPI/ Urban\%20Pathways\%20to\%20Healthy\%20Neighborhoods_Safety_letter.pdf.

Rails-to-Trails Conservancy. Urban Pathways to Healthy Neighborhoods. Accessed September 5, 2014. http://www. railstotrails.org/ourWork/promotingTrailUse/urbanpathways/issue-summaries/safety.html.

Ren, Wanxia, , Bing Xue, Yong Geng, Lina Sun, Zhixiao Ma, Yunsong Zhang,Bruce Mitchell, and Liming Zhang. "Inventorying Heavy Metal Pollution in Redeveloped Brownfield and Its Policy Contribution: Case Study from Tiexi District, Shenyang, China." Land Use Policy 38 (2014): 138-146.

Schwarz, Peter M., Craig A. Depken, Alex Hanning, Kristen Peterson, "Comparing Contaminated Property Redevelopment for Mandatory and Voluntary Cleanup Programs in California." Journal of Environmental Management 90 (2009): 3730-3735.

Sherer, Paul M. "The Benefits of Parks, Why America Needs More City Parks and Open Space." The Trust for Public Land, 2003. Accessed February 10, 2014. http://www.eastshorepark.org/benefits_of_parks\%20tpl.pdf.

Sichley, Sara Lynn. "Brownfield Cleanup in a Post-Redevelopment Era: Using a Collaborative, Community-Based Approach to Green the Spartan-Keyes Neighborhood.” master’s thesis, San Jose States University, 2013.

St. Petersburg Police Department. What is CPTED?. Accessed September 5, 2014. http://www.stpete.org/police/pdf/ crime-prev/CPTED-brochure.pdf.

Swartjes, F. A., M. Rutgers, J.P.A. Lijzen, P.J.C.M. Janssen, P.F. Otte, A. Wintersen, E. Brand, and L. Posthuma. "State of the Art of Contaminated Site Management in the Netherlands: Policy Framework and Risk Assessment Tools." Science of the Total Environment 427-428 (2012): 1-10.

Tam, Edwin K. L., and Philip H. Byer. "Remediation of Contaminated Lands: A Decision Methodology for Site Owners." Journal of Environmental Management 64 (2002): 387-400.

United Nations Interregional Crime and Justice. Improving Urban Security through Green Environmental Design. Accessed November 30, 2014. http://www.unicri.it/news/files/2011-04-01_110414_CRA_Urban_Security_ sm.pdf. 
United States Environmental Protection Agency. “Brownfields and Land Revitalization.” Last modified July 16, 2012. Accessed February 22, 2014. http://www.epa.gov/brownfields/basic_info.htm.

United States Environmental Protection Agency. Cleanup sites in California. Accessed April 4, 2014, http://www.epa. gov/region9/cleanup/california.html.

United Sates Environmental Protection Agency. "Land and Cleanup." last modified January 15, 2014. Accessed February 22, 2014. http://www2.epa.gov/regulatory-information-topic/land-and-cleanup\#brown.

United States Environmental Protection Agency. “Laws and Statutes.” Last modified January 15, 2014. Accessed February 22, 2014, http://www.epa.gov/brownfields/laws/index.htm.

United States Environmental Protecting Agency. “The Brownfield Program: Setting Change in Motion.” 2002. Accessed April 22, 2014, https://play.google.com/

booksreader?id=O0jfrK986ykC\&printsec=frontcover\&output=reader\&authuser=0\&hl=en \&pg=GBS.PT1.

United States Department of Labor. "Brownfields Health \& Safety for Sites Evaluated \& Remediated under Federal Brownfields Initiatives or State Voluntary Clean-up Programs.” Accessed February 22, 2014. https://www. osha.gov/SLTC/brownfields/brnfld_qna.html.

Winson-Geidman K., R.A. Simons, and J. Pendergrass. “Tracking Remediation and Redevelopment Trends of Brownfield Cleanup Programs: The Cook County Experience," Journal of Environmental Planning and Management 47 (2004): 393-405, quoted in G.W. Page, R.S. Berger, "Characteristics and Land Use of Contaminated Brownfield Properties in Voluntary Cleanup Agreement Programs," Land Use Policy 23 (2006): $551-559$. 